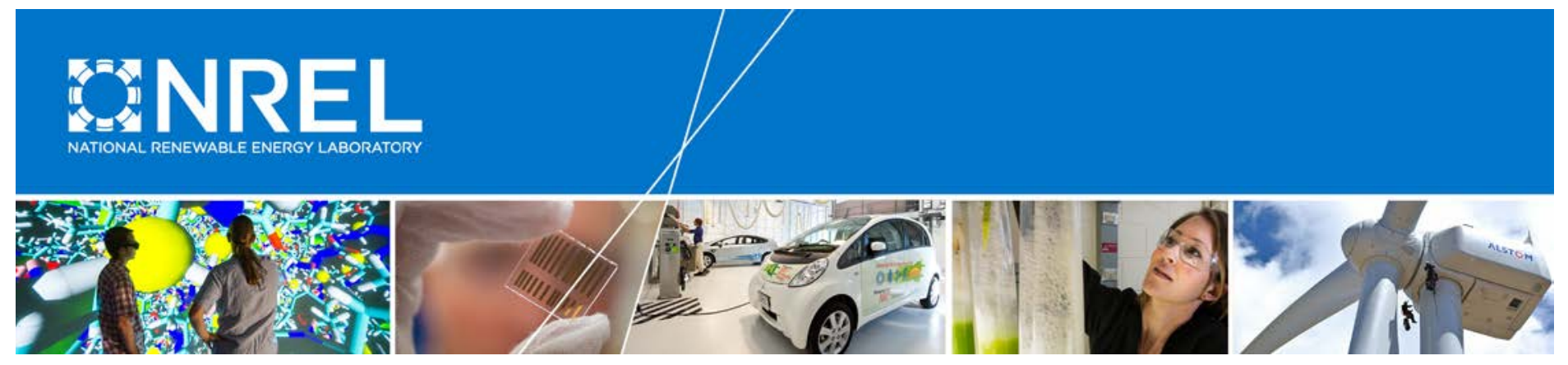

\title{
Marine and Hydrokinetic Technology Development Risk Management Framework
}

David Snowberg and Jochem Weber

Link to Risk Register Template

NREL is a national laboratory of the U.S. Department of Energy Office of Energy Efficiency \& Renewable Energy Operated by the Alliance for Sustainable Energy, LLC

This report is available at no cost from the National Renewable Energy Laboratory (NREL) at www.nrel.gov/publications.

Technical Report

NREL/TP-5000-63258

September 2015

Contract No. DE-AC36-08GO28308 


\title{
Marine and Hydrokinetic Technology Development Risk Management Framework
}

\author{
David Snowberg and Jochem Weber
}

Prepared under Task No(s). WA09.3501

NREL is a national laboratory of the U.S. Department of Energy Office of Energy Efficiency \& Renewable Energy Operated by the Alliance for Sustainable Energy, LLC

This report is available at no cost from the National Renewable Energy Laboratory (NREL) at www.nrel.gov/publications.

National Renewable Energy Laboratory 15013 Denver West Parkway Golden, CO 80401

303-275-3000 • www.nrel.gov

\section{Technical Report}

NREL/TP-5000-63258

September 2015

Contract No. DE-AC36-08GO28308 


\title{
NOTICE
}

This report was prepared as an account of work sponsored by an agency of the United States government. Neither the United States government nor any agency thereof, nor any of their employees, makes any warranty, express or implied, or assumes any legal liability or responsibility for the accuracy, completeness, or usefulness of any information, apparatus, product, or process disclosed, or represents that its use would not infringe privately owned rights. Reference herein to any specific commercial product, process, or service by trade name, trademark, manufacturer, or otherwise does not necessarily constitute or imply its endorsement, recommendation, or favoring by the United States government or any agency thereof. The views and opinions of authors expressed herein do not necessarily state or reflect those of the United States government or any agency thereof.

This report is available at no cost from the National Renewable Energy Laboratory (NREL) at www.nrel.gov/publications.

Available electronically at SciTech Connect http:/www.osti.gov/scitech

Available for a processing fee to U.S. Department of Energy and its contractors, in paper, from:

\author{
U.S. Department of Energy \\ Office of Scientific and Technical Information \\ P.O. Box 62 \\ Oak Ridge, TN 37831-0062 \\ OSTI http://www.osti.gov \\ Phone: 865.576.8401 \\ Fax: 865.576.5728 \\ Email: reports@osti.gov
}

Available for sale to the public, in paper, from:

\author{
U.S. Department of Commerce \\ National Technical Information Service \\ 5301 Shawnee Road \\ Alexandria, VA 22312 \\ NTIS http://www.ntis.gov \\ Phone: 800.553 .6847 or 703.605 .6000 \\ Fax: 703.605.6900 \\ Email: orders@ntis.gov
}




\section{Table of Contents}

Marine and Hydrokinetic Technology Development Risk Management Framework .......................... 4

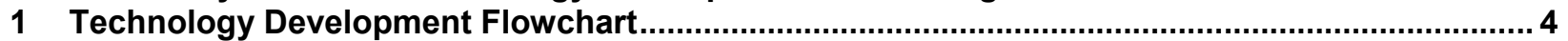

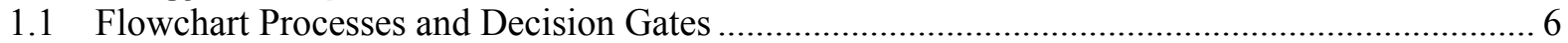

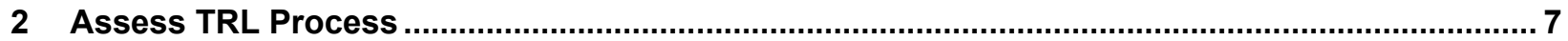

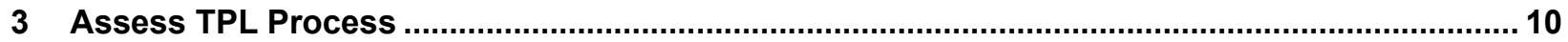

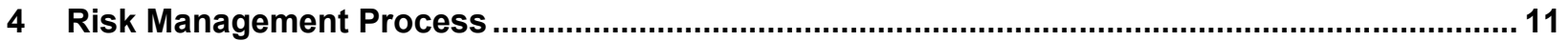

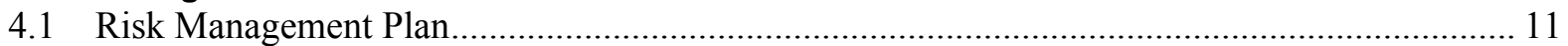

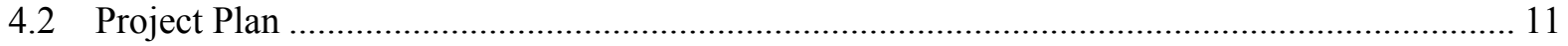

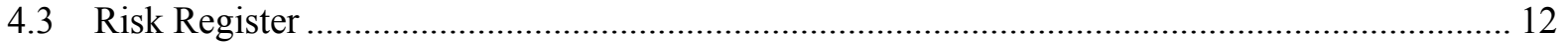

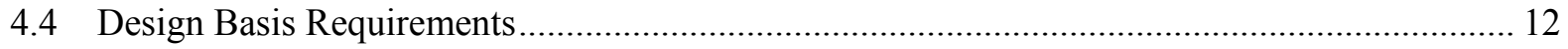

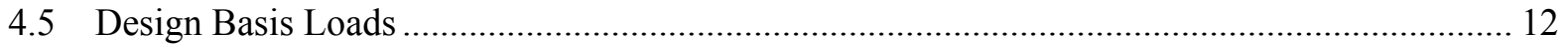

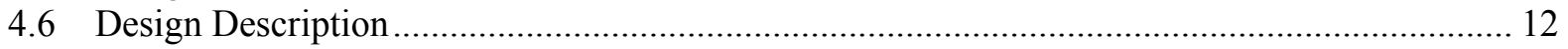

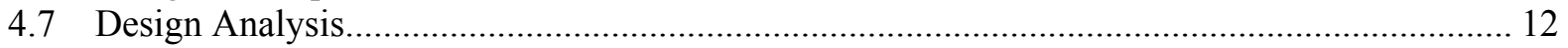

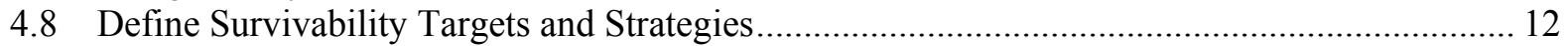

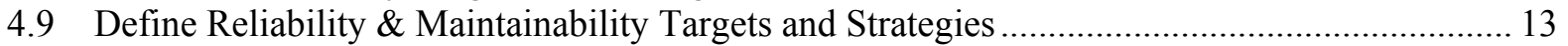

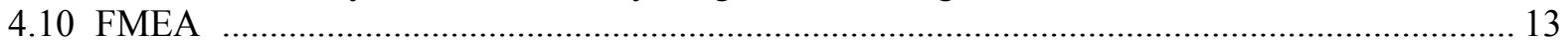

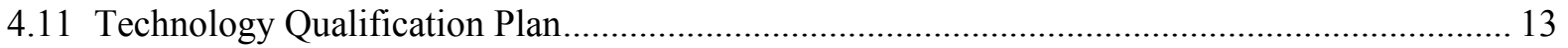

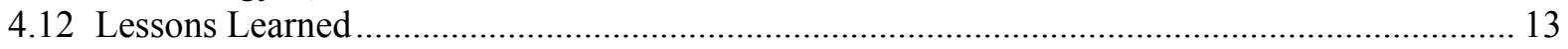

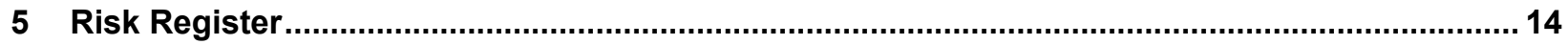

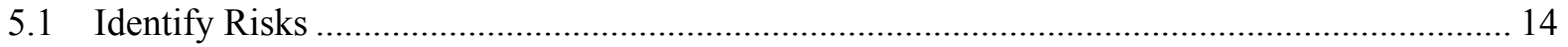

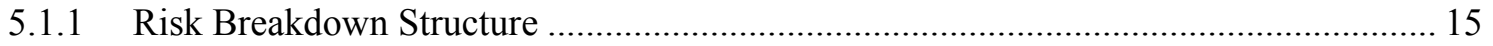

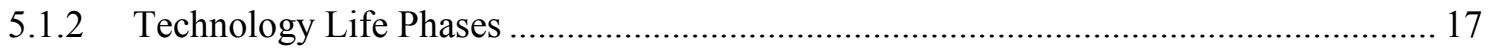

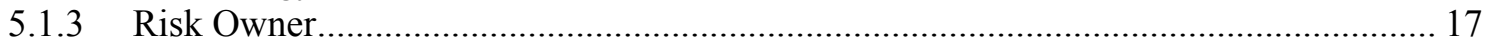

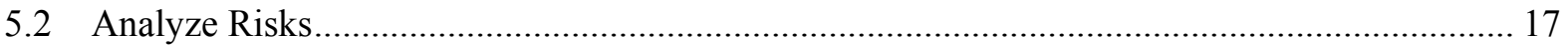

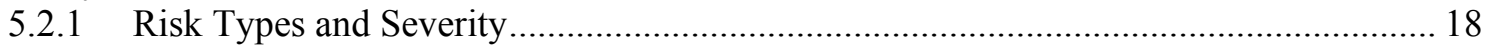

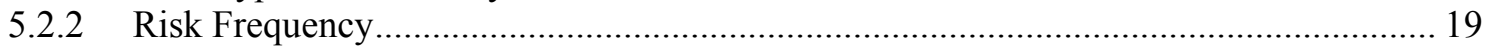

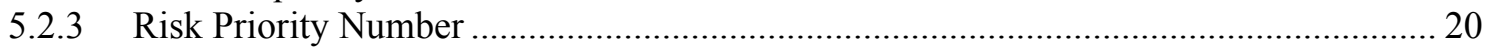

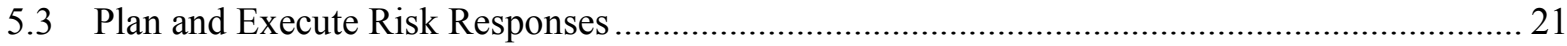

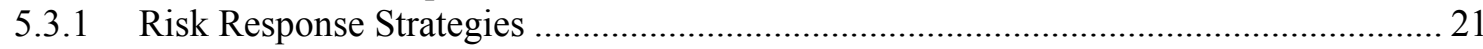

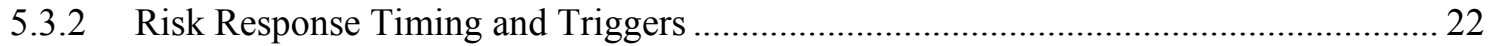

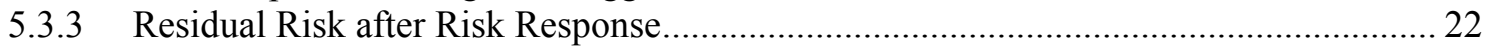

5.3.4 Secondary Risks Resulting from Risk Response .................................................... 22

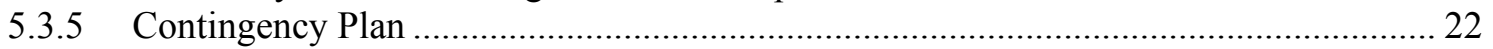

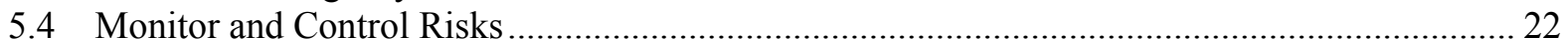

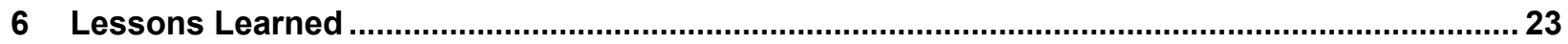

6.1 Definitions for Terms Used Within the Fields from Table 9 and Table 10: ........................... 25

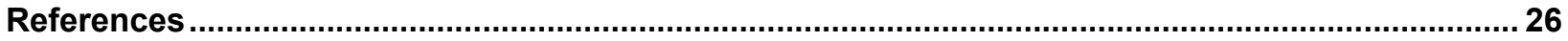

Appendix A-Risk Management Checklist for DOE Funding Opportunity Announcement (FOA)

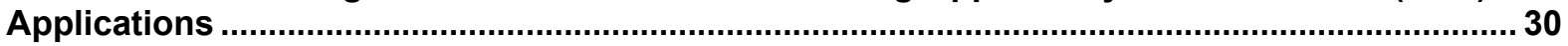

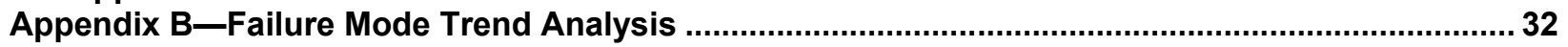

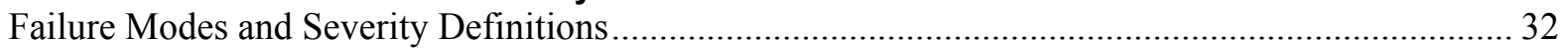

Failure Mode Trend Analysis Hypothetical Example \#1 .......................................................... 34

Appendix C—Risk Management Outlined Bibliography (Standards, Guides \& Reports) ................ 39

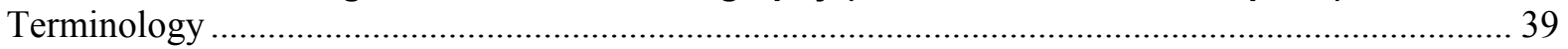

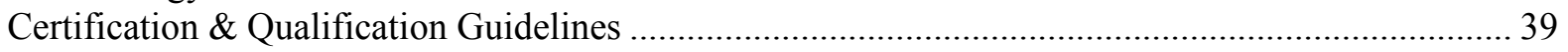

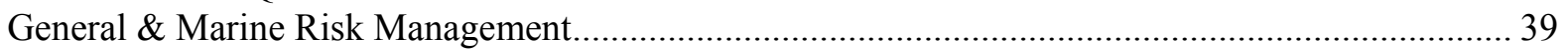

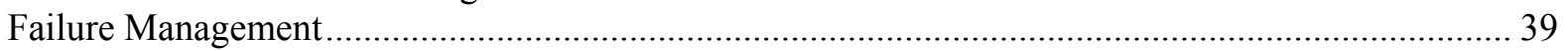

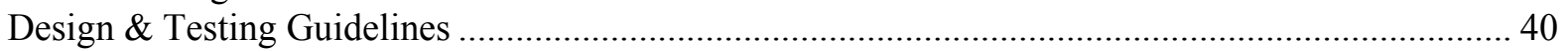

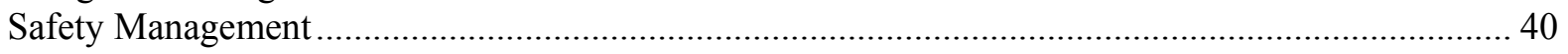

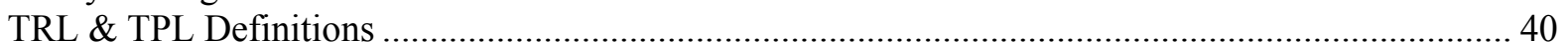




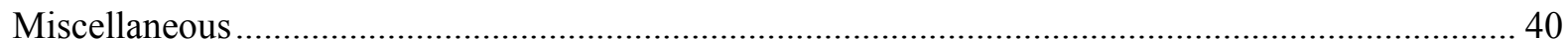

Appendix D-MHK Lessons Learned (Publically Available Information): ........................................ 42

Breach of Water Integrity of Compartments or Equipment: ....................................................... 42

Electrical Failures and Shore Connector Failures / Pressure Containment Failure from Hydraulic or

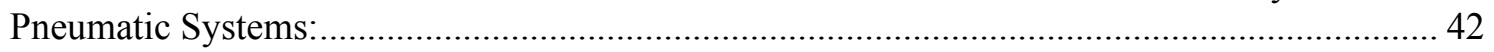

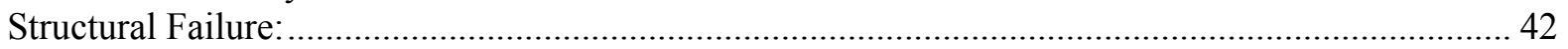

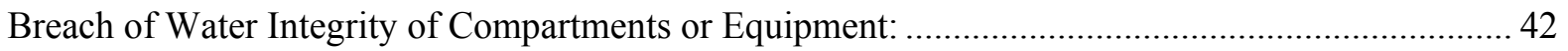

Electrical Failures and Shore Connector Failures / Structural Failure: ............................................ 42

Mooring Failure / Breach of Water Integrity of Compartments or Equipment: ................................. 42

Breach of Water Integrity of Compartments or Equipment / Bankruptcy: ....................................... 43

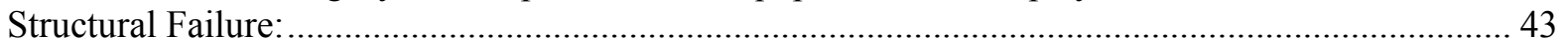

Structural Failure / Breach of Water Integrity of Compartments or Equipment / Regulatory: ............ 43

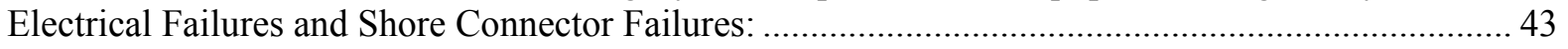

Breach of Water Integrity of Compartments or Equipment / Bankruptcy: ......................................... 43

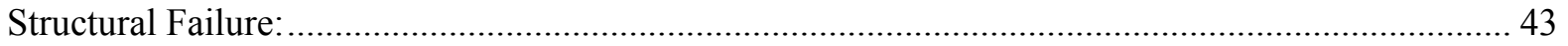

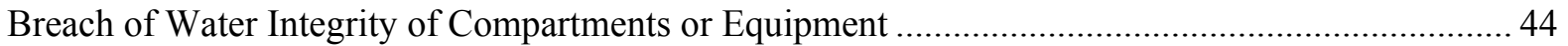

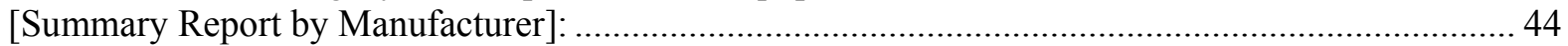

\section{List of Figures}

Figure 1. Risk management in the MHK technology development flowchart....................................... 5

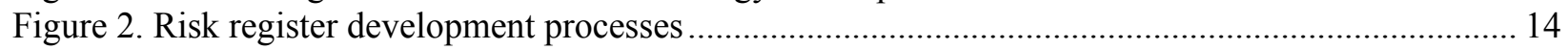

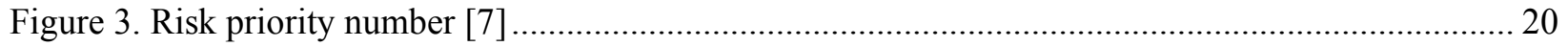

Figure 4. Hypothetical analysis \#1 — failure mode occurrences during Period 1 1.................................... 37

Figure 5. Hypothetical analysis \#1 — failure trends over three periods for Failure Mode 7....................... 38

\section{List of Tables}

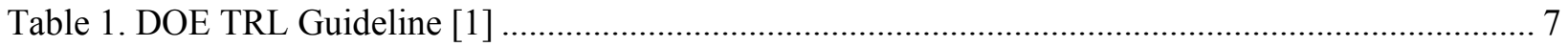

Table 2. Technology Performance Levels - Categories and Characteristics [3] ..................................... 10

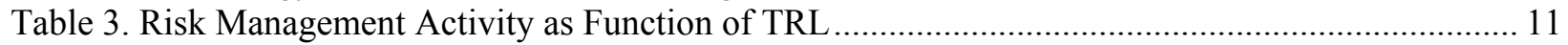

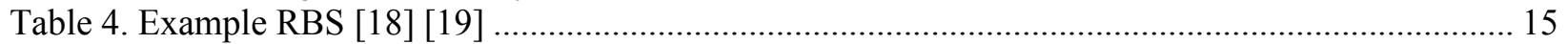

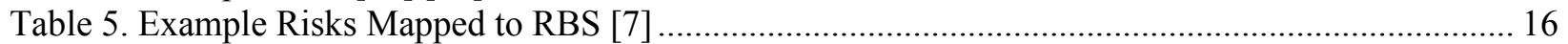

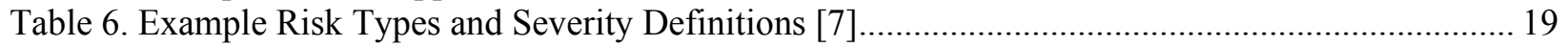

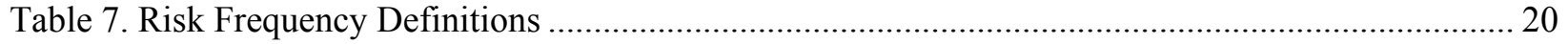

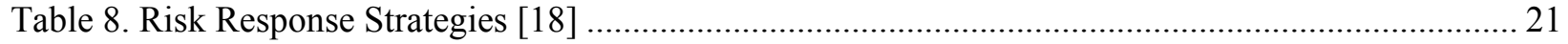

Table 9. Template for Lessons-Learned Issues (Mock Data Shown) ......................................................2 24

Table 10. Template for Lessons-Learned Successes (Mock Data Shown) ............................................... 24

Table 11. Failure Mode Severity Definitions for Trend Analysis …...................................................... 32

Table 12. Hypothetical Example \#1 —Failure Trend Analysis Period 1 ................................................. 34

Table 13. Hypothetical Example \#1-Failure Trend Analysis Period 2................................................ 35

Table 14. Hypothetical Example \#1—Failure Trend Analysis Period 3.................................................. 36 


\section{List of Acronyms}

\begin{tabular}{|c|c|}
\hline ABS & American Bureau of Shipping \\
\hline ALARA & as low as reasonably achievable \\
\hline API & American Petroleum Institute \\
\hline CBS & cost breakdown structure \\
\hline DNV & Det Norske Veritas \\
\hline DOD & U.S. Department of Defense \\
\hline DOE & U.S. Department of Energy \\
\hline EMEC & European Marine Energy Centre \\
\hline ESBI & Electricity Supply Board International (Ireland) \\
\hline EWTEC & European Wave and Tidal Energy Conference \\
\hline FMEA & failure mode effects analysis \\
\hline FOA & funding opportunity announcement \\
\hline FRQ & frequency of risk \\
\hline GL & Germanischer Lloyd \\
\hline GUM & $\begin{array}{l}\text { Guide to the Expression of Uncertainty in } \\
\text { Measurement }\end{array}$ \\
\hline HSE & Health \& Safety Executive \\
\hline ICOE & International Conference on Ocean Energy \\
\hline IEC & International Electrotechnical Commission \\
\hline IMCA & International Marine Contractors Association \\
\hline ITTC & International Towing Tank Conference \\
\hline JCGM & Joint Committee for Guides in Metrology \\
\hline LCOE & levelized cost of energy \\
\hline MEC & marine energy converters \\
\hline MFOP & maintenance free operating periods \\
\hline MHK & marine and hydrokinetic \\
\hline MRP & maintenance recovery period \\
\hline MTBF & mean time between failures \\
\hline MTTR & mean time to repair \\
\hline NASA & National Aeronautics and Space Administration \\
\hline NREL & National Renewable Energy Laboratory \\
\hline OES & Ocean Energy Systems \\
\hline OREDA & Offshore REliability DAta \\
\hline PMBOK & Project Management Body of Knowledge \\
\hline PMI & Project Management Institute \\
\hline PTO & power take-off \\
\hline RBS & risk breakdown structure \\
\hline $\mathrm{RPN}$ & risk priority number \\
\hline SOP & safe operating procedure \\
\hline SEV & severity of risk \\
\hline TBD & to be determined \\
\hline TPL & technology performance level \\
\hline TRL & technology readiness level \\
\hline TYP & risk type \\
\hline WEC & wave energy converter \\
\hline
\end{tabular}




\section{Marine and Hydrokinetic Technology Development Risk Management Framework}

Over the past decade, the global marine and hydrokinetic (MHK) industry has suffered a number of serious technological and commercial setbacks. To help reduce the risks of industry failures and advance the development of new technologies, the U.S. Department of Energy (DOE) and the National Renewable Energy Laboratory (NREL) developed an MHK Risk Management Framework.

By addressing uncertainties, the MHK Risk Management Framework increases the likelihood of successful development of an MHK technology. It covers projects of any technical readiness level (TRL) or technical performance level (TPL) and all risk types (e.g. technological risk, regulatory risk, commercial risk) over the development cycle. This framework is intended for the development and deployment of a single MHK technology—not for multiple device deployments within a plant.

This risk framework is intended to meet DOE's risk management expectations for the MHK technology research and development efforts of the Water Power Program (see Appendix A). It also provides an overview of other relevant risk management tools and documentation. ${ }^{1}$

This framework emphasizes design and risk reviews as formal gates to ensure risks are managed throughout the technology development cycle. Section 1 presents the recommended technology development cycle, Sections 2 and 3 present tools to assess the TRL and TPL of the project, respectively. Section 4 presents a risk management process with design and risk reviews for actively managing risk within the project, and Section 5 presents a detailed description of a risk registry to collect the risk management information into one living document. Section 6 presents recommendations for collecting and using lessons learned throughout the development process.

\section{Technology Development Flowchart}

Figure 1 contains a flowchart of a typical development cycle seen in MHK component-level, subsystem-level, and system-level design and testing. The steps and decision gates are defined in Section 1.1. For developing individual components or subsystems in parallel to a full system, the processes in Figure 1 should be applied separately for each development.

\footnotetext{
${ }^{1}$ Embedded hyperlinks (underlined text) to external references are included. The long-term integrity of these external links cannot be ensured and if hyperlinks are not functioning, then consult the References section for the formal reference.
} 


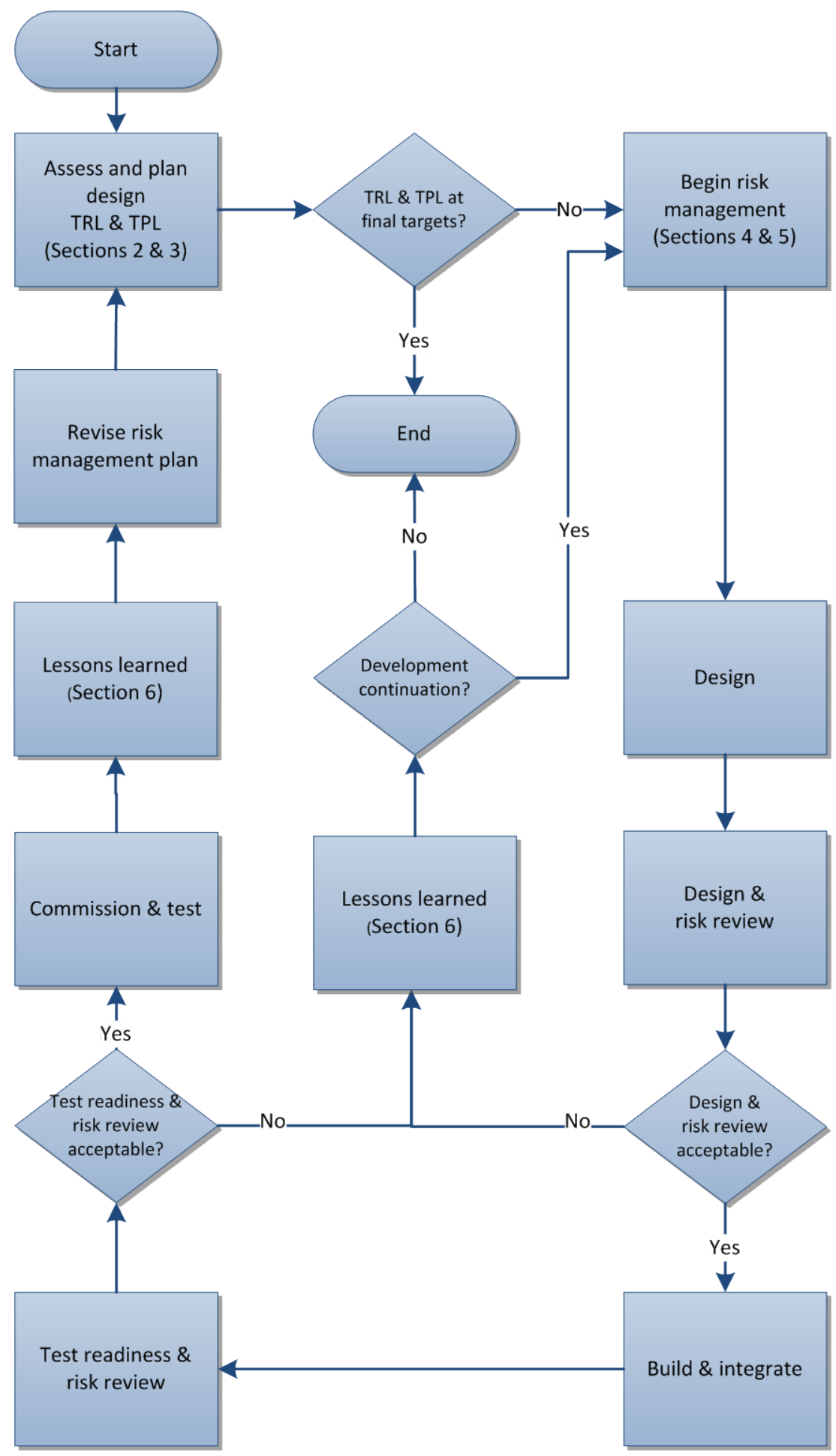

Figure 1. Risk management in the MHK technology development flowchart 


\subsection{Flowchart Processes and Decision Gates}

Assess and plan design TRL and TPL: Categorize the current state of TRL and TPL for the system and/or its components. The plan is the incremental TRL and TPL targets for subsequent development cycles. See Sections 2 and 3 for details on assessment criteria.

TRL and TPL at final targets?: Determine if the existing TRL and TPL values for the system and/or its components have reached the final targets.

Begin risk management: Develop and begin implementing a risk management plan (Section 4.1). The risk management requirements at each TRL are detailed in Table 3. The risk management plan may be based on this MHK Risk Management Framework document, or it may be based on equivalent processes within an organization. The process of identifying, analyzing, monitoring, and controlling risks continues throughout the development cycle, Figure 1.

Design: Design the system and/or its components.

Design and risk review: Prior to build and testing, review the design and risks. All of the pertinent Table 3 items should be reviewed during this process. The review should be based on: 1) design with documentation; 2) risk management completion, per Table 3; and 3) acceptable risk management results.

Design and risk review acceptable?: Determine if the design and risks are acceptable. This review can be a go/no-go gate for DOE or others to monitor the technology development.

Development continuation?: For failed decision gates, determine if the technology development should continue after capturing lessons learned. To do this, evaluate the identified negative risks (threats) and costs of the project against the positive risks (opportunities) and benefits. A decision to not continue development moves to the termination of the project short of the TRL or TPL goal, and a decision to continue returns the cycle's risk management planning stage.

Build and integrate: Build and integrate the components and subsystems for testing.

Test readiness and risk review: Review the built and integrated system and/or components/subsystems before testing. This process should include a risk review with particular emphasis on the technology qualification plan. All of the pertinent Table 3 items should be reviewed during this process. Review should be based on: 1) verification showing built equipment is the approved design; 2) risk management completion, per Table 3; and 3) acceptable risk management results.

Test readiness and risk review acceptable?: Decide if the system or components are ready for testing. This review can be a go/no-go gate.

Commission and test: Execute the test plan at the system- and/or component/subsystem-level.

Lessons learned: Gather lessons learned to formalize institutional learning. Identify specific problems and recommendations to avoid reoccurrence, successes that can be used in the future, 
and risk management improvements. Section 6 provides additional details for documenting lessons learned.

Revise risk management plan: Revise the risk management plan (Section 4.1) based on information documented during the lessons learned process. The risk management plan is modified to ensure it continues to be valuable for the team.

\section{Assess TRL Process}

DOE's TRL definitions are used to assess the commercial readiness (technology maturity) of the MHK technology and to guide the technology development cycle. Table 1 contains the TRL definitions from the DOE Technology Readiness Assessment Guide [1].

Table 1. DOE TRL Guideline [1]

\begin{tabular}{|c|c|c|c|}
\hline $\begin{array}{l}\text { Relative Level } \\
\text { of Technology } \\
\text { Development }\end{array}$ & $\begin{array}{l}\text { Technology } \\
\text { Readiness } \\
\text { Level (TRL) }\end{array}$ & $\begin{array}{l}\text { TRL } \\
\text { Definition }\end{array}$ & Description \\
\hline $\begin{array}{l}\text { System } \\
\text { Operations }\end{array}$ & TRL 9 & $\begin{array}{l}\text { Actual system } \\
\text { operated over } \\
\text { the full range } \\
\text { of expected } \\
\text { mission } \\
\text { conditions. }\end{array}$ & $\begin{array}{l}\text { The technology is in its final form and operated under the full } \\
\text { range of operating mission conditions. Examples include using the } \\
\text { actual system with the full range of wastes in hot operations. }\end{array}$ \\
\hline \multirow[t]{2}{*}{$\begin{array}{l}\text { System } \\
\text { Commissioning }\end{array}$} & TRL 8 & $\begin{array}{l}\text { Actual system } \\
\text { completed and } \\
\text { qualified } \\
\text { through test } \\
\text { and } \\
\text { demonstration. }\end{array}$ & $\begin{array}{l}\text { The technology has been proven to work in its final form and } \\
\text { under expected conditions. In almost all cases, this TRL } \\
\text { represents the end of true system development. Examples include } \\
\text { developmental testing and evaluation of the system with actual } \\
\text { waste in hot commissioning. Supporting information includes } \\
\text { operational procedures that are virtually complete. An Operational } \\
\text { Readiness Review has been successfully completed prior to the } \\
\text { start of hot testing. }\end{array}$ \\
\hline & TRL 7 & $\begin{array}{l}\text { Full-scale, } \\
\text { similar } \\
\text { (prototypical) } \\
\text { system } \\
\text { demonstrated } \\
\text { in relevant } \\
\text { environment. }\end{array}$ & $\begin{array}{l}\text { This represents a major step up from TRL } 6 \text {, requiring } \\
\text { demonstration of an actual system prototype in a relevant } \\
\text { environment. Examples include testing full-scale prototype in the } \\
\text { field with a range of simulants in cold commissioning. }{ }^{1} \text { Supporting } \\
\text { information includes results from the full-scale testing and } \\
\text { analysis of the differences between the test environment, and } \\
\text { analysis of what the experimental results mean for the eventual } \\
\text { operating system/environment. Final design is virtually complete. }\end{array}$ \\
\hline
\end{tabular}




\begin{tabular}{|c|c|c|c|}
\hline $\begin{array}{l}\text { Relative Level } \\
\text { of Technology } \\
\text { Development }\end{array}$ & $\begin{array}{l}\text { Technology } \\
\text { Readiness } \\
\text { Level (TRL) }\end{array}$ & $\begin{array}{l}\text { TRL } \\
\text { Definition }\end{array}$ & Description \\
\hline $\begin{array}{l}\text { Technology } \\
\text { Demonstration }\end{array}$ & TRL 6 & $\begin{array}{l}\text { Engineering/pi- } \\
\text { lot-scale, } \\
\text { similar } \\
\text { (prototypical) } \\
\text { system } \\
\text { validation in } \\
\text { relevant } \\
\text { environment. }\end{array}$ & $\begin{array}{l}\text { Engineering-scale models or prototypes are tested in a relevant } \\
\text { environment. This represents a major step up in a technology's } \\
\text { demonstrated readiness. Examples include testing an engineering } \\
\text { scale prototypical system with a range of simulants. }{ }^{1} \text { Supporting } \\
\text { information includes results from the engineering scale testing } \\
\text { and analysis of the differences between the engineering scale, } \\
\text { prototypical system/environment, and analysis of what the } \\
\text { experimental results mean for the eventual operating } \\
\text { system/environment. TRL } 6 \text { begins true engineering development } \\
\text { of the technology as an operational system. The major difference } \\
\text { between TRL } 5 \text { and } 6 \text { is the step up from laboratory scale to } \\
\text { engineering scale and the determination of scaling factors that will } \\
\text { enable design of the operating system. The prototype should be } \\
\text { capable of performing all the functions that will be required of the } \\
\text { operational system. The operating environment for the testing } \\
\text { should closely represent the actual operating environment. }\end{array}$ \\
\hline $\begin{array}{l}\text { Technology } \\
\text { Development }\end{array}$ & TRL 5 & $\begin{array}{l}\text { Laboratory } \\
\text { scale, similar } \\
\text { system } \\
\text { validation in } \\
\text { relevant } \\
\text { environment. }\end{array}$ & $\begin{array}{l}\text { The basic technological components are integrated so that the } \\
\text { system configuration is similar to (matches) the final application in } \\
\text { almost all respects. Examples include testing a high-fidelity, } \\
\text { laboratory scale system in a simulated environment with a range } \\
\text { of simulants }{ }^{1} \text { and actual waste. }{ }^{2} \text { Supporting information includes } \\
\text { results from the laboratory scale testing, analysis of the } \\
\text { differences between the laboratory and eventual operating } \\
\text { system/environment, and analysis of what the experimental } \\
\text { results mean for the eventual operating system/environment. The } \\
\text { major difference between TRL } 4 \text { and } 5 \text { is the increase in the } \\
\text { fidelity of the system and environment to the actual application. } \\
\text { The system tested is almost prototypical. }\end{array}$ \\
\hline $\begin{array}{l}\text { Technology } \\
\text { Development }\end{array}$ & TRL 4 & $\begin{array}{l}\text { Component } \\
\text { and/or system } \\
\text { validation in } \\
\text { laboratory } \\
\text { environment. }\end{array}$ & $\begin{array}{l}\text { The basic technological components are integrated to establish } \\
\text { that the pieces will work together. This is relatively "low fidelity" } \\
\text { compared with the eventual system. Examples include integration } \\
\text { of ad hoc hardware in a laboratory and testing with a range of } \\
\text { simulants and small scale tests on actual waste. } \\
\text { information includes the results of the integrated experiments and } \\
\text { estimates of how the experimental components and experimental } \\
\text { test results differ from the expected system performance goals. } \\
\text { TRL } 4-6 \text { represent the bridge from scientific research to } \\
\text { engineering. TRL } 4 \text { is the first step in determining whether the } \\
\text { individual components will work together as a system. The } \\
\text { laboratory system will probably be a mix of on hand equipment } \\
\text { and a few special purpose components that may require special } \\
\text { handling, calibration, or alignment to get them to function. }\end{array}$ \\
\hline
\end{tabular}




\begin{tabular}{|c|c|c|c|}
\hline $\begin{array}{l}\text { Relative Level } \\
\text { of Technology } \\
\text { Development }\end{array}$ & $\begin{array}{l}\text { Technology } \\
\text { Readiness } \\
\text { Level (TRL) }\end{array}$ & $\begin{array}{l}\text { TRL } \\
\text { Definition }\end{array}$ & Description \\
\hline \multirow[t]{2}{*}{$\begin{array}{l}\text { Research to } \\
\text { Prove } \\
\text { Feasibility }\end{array}$} & TRL 3 & $\begin{array}{l}\text { Analytical and } \\
\text { experimental } \\
\text { critical function } \\
\text { and/or } \\
\text { characteristic } \\
\text { proof of } \\
\text { concept. }\end{array}$ & $\begin{array}{l}\text { Active research and development (R\&D) is initiated. This includes } \\
\text { analytical studies and laboratory-scale studies to physically } \\
\text { validate the analytical predictions of separate elements of the } \\
\text { technology. Examples include components that are not yet } \\
\text { integrated or representative tested with simulants. }{ }^{1} \text { Supporting } \\
\text { information includes results of laboratory tests performed to } \\
\text { measure parameters of interest and comparison to analytical } \\
\text { predictions for critical subsystems. At TRL } 3 \text {, the work has moved } \\
\text { beyond the paper phase to experimental work that verifies that the } \\
\text { concept works as expected on simulants. Components of the } \\
\text { technology are validated, but there is no attempt to integrate the } \\
\text { components into a complete system. Modeling and simulation } \\
\text { may be used to complement physical experiments. }\end{array}$ \\
\hline & \multirow[t]{2}{*}{ TRL 2} & \multirow[t]{2}{*}{$\begin{array}{l}\text { Technology } \\
\text { concept and/or } \\
\text { application } \\
\text { formulated. }\end{array}$} & $\begin{array}{l}\text { Once basic principles are observed, practical applications can be } \\
\text { invented. Applications are speculative, and there may be no proof } \\
\text { or detailed analysis to support the assumptions. Examples are still } \\
\text { limited to analytic studies. }\end{array}$ \\
\hline \multirow[t]{2}{*}{$\begin{array}{l}\text { Basic } \\
\text { Technology } \\
\text { Research }\end{array}$} & & & $\begin{array}{l}\text { Supporting information includes publications or other references } \\
\text { that outline the application being considered and that provide } \\
\text { analysis to support the concept. The step up from TRL } 1 \text { to TRL } 2 \\
\text { moves the ideas from pure to applied research. Most of the work } \\
\text { is analytical or paper studies with the emphasis on understanding } \\
\text { the science better. Experimental work is designed to corroborate } \\
\text { the basic scientific observations made during TRL } 1 \text { work. }\end{array}$ \\
\hline & TRL 1 & $\begin{array}{l}\text { Basic } \\
\text { principles } \\
\text { observed and } \\
\text { reported. }\end{array}$ & $\begin{array}{l}\text { This is the lowest level of technology readiness. Scientific } \\
\text { research begins to be translated into applied R\&D. Examples } \\
\text { might include paper studies of a technology's basic properties or } \\
\text { experimental work that consists mainly of observations of the } \\
\text { physical world. Supporting Information includes published } \\
\text { research or other references that identify the principles that } \\
\text { underlie the technology. }\end{array}$ \\
\hline
\end{tabular}

${ }^{1}$ Simulants should match relevant chemical and physical properties.

${ }^{2}$ Testing with as wide a range of actual waste as practicable and consistent with waste availability, safety, ALARA, cost and project risk is highly desirable. 


\section{Assess TPL Process}

The TPL metric is complementary to the TRL metric; it is used to quantify the techno-economic performance potential of a technology [2]. The combination of TRL and TPL provides a complete representation of the status of technology under development toward commercial readiness and economic viability and serves well as a set of metrics to quantify and assess development progress. Development steps targeting the improvement of technology performance may be quantified by a TPL or another techno-economic performance metric.

Table 2 contains the TPL definitions [3].

Table 2. Technology Performance Levels - Categories and Characteristics [3]

\begin{tabular}{|c|c|c|c|}
\hline \multirow[b]{2}{*}{ TPL } & & \multirow{2}{*}{$\begin{array}{l}\text { Category } \\
\text { Characteristic }\end{array}$} & \multirow{2}{*}{$\begin{array}{l}\text { TPL } \\
\text { Characteristics }\end{array}$} \\
\hline & & & \\
\hline 9 & \multirow{3}{*}{ 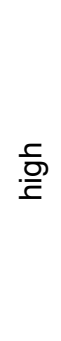 } & \multirow{3}{*}{$\begin{array}{l}\text { Technology is } \\
\text { economically viable and } \\
\text { competitive as a } \\
\text { renewable energy } \\
\text { source. }\end{array}$} & $\begin{array}{l}\text { Competitive with other energy sources without any } \\
\text { support mechanism. }\end{array}$ \\
\hline 8 & & & $\begin{array}{l}\text { Competitive with other energy sources given } \\
\text { sustainable (e.g. low feed-in tariff) support } \\
\text { mechanism. }\end{array}$ \\
\hline 7 & & & $\begin{array}{l}\text { Competitive with other renewable energy sources } \\
\text { given favorable (e.g. high feed-in tariffs) support } \\
\text { mechanism. }\end{array}$ \\
\hline 6 & \multirow{3}{*}{ 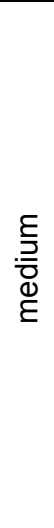 } & \multirow{3}{*}{$\begin{array}{l}\text { Technology features } \\
\text { some characteristics for } \\
\text { potential economic } \\
\text { viability under distinctive } \\
\text { market and operational } \\
\text { conditions. Technological } \\
\text { or conceptual } \\
\text { improvements may be } \\
\text { required. }\end{array}$} & $\begin{array}{l}\text { Majority of key performance characteristics and cost } \\
\text { drivers satisfy potential economic viability under } \\
\text { distinctive and favorable market and operational } \\
\text { conditions. }\end{array}$ \\
\hline 5 & & & $\begin{array}{l}\text { To achieve economic viability under distinctive and } \\
\text { favorable market and operational conditions, some } \\
\text { key technology implementation improvements are } \\
\text { required and regarded as possible. }\end{array}$ \\
\hline 4 & & & $\begin{array}{l}\text { To achieve economic viability under distinctive and } \\
\text { favorable market and operational conditions, some } \\
\text { key technology implementation and fundamental } \\
\text { conceptual improvements are required and } \\
\text { regarded as possible. }\end{array}$ \\
\hline 3 & \multirow{3}{*}{ 으 } & \multirow{3}{*}{$\begin{array}{l}\text { Technology is not } \\
\text { economically viable. }\end{array}$} & $\begin{array}{l}\text { Minority of key performance characteristics and cost } \\
\text { drivers do not satisfy potential economic viability } \\
\text { and critical improvements are not regarded as } \\
\text { possible within fundamental concept. }\end{array}$ \\
\hline 2 & & & $\begin{array}{l}\text { Some key performance characteristics and cost } \\
\text { drivers do not satisfy potential economic viability } \\
\text { and critical improvements are not regarded as } \\
\text { possible within fundamental concept. }\end{array}$ \\
\hline 1 & & & $\begin{array}{l}\text { Majority of key performance characteristics and cost } \\
\text { drivers do not satisfy and present a barrier to } \\
\text { potential economic viability and critical } \\
\text { improvements are not regarded as possible within } \\
\text { fundamental concept. }\end{array}$ \\
\hline
\end{tabular}




\section{Risk Management Process}

Table 3 contains the TRL-specific risk management activities to be completed for each technology development cycle. Each item within this table is described in subsequent subsections. The order of activities in Table 3 approximates the flow within a development cycle (Figure 1).

Table 3. Risk Management Activity as Function of TRL

\begin{tabular}{|l|l|l|l|l|l|l|l|l|l|l|l|}
\hline \multicolumn{7}{|l|}{ Activity Required at TRL Level } & \multicolumn{2}{l}{ Risk Management Activity } & \\
\hline 1 & $\mathbf{2}$ & $\mathbf{3}$ & $\mathbf{4}$ & $\mathbf{5}$ & $\mathbf{6}$ & $\mathbf{7}$ & $\mathbf{8}$ & $\mathbf{9}$ & & \\
\hline $\mathrm{x}$ & $\mathrm{x}$ & $\mathrm{x}$ & $\mathrm{x}$ & $\mathrm{x}$ & $\mathrm{x}$ & $\mathrm{x}$ & $\mathrm{x}$ & $\mathrm{x}$ & Risk management plan & 4.1 \\
\hline $\mathrm{x}$ & $\mathrm{x}$ & $\mathrm{x}$ & $\mathrm{x}$ & $\mathrm{x}$ & $\mathrm{x}$ & $\mathrm{x}$ & $\mathrm{x}$ & $\mathrm{x}$ & Project plan & 4.2 \\
\hline $\mathrm{x}$ & $\mathrm{x}$ & $\mathrm{x}$ & $\mathrm{x}$ & $\mathrm{x}$ & $\mathrm{x}$ & $\mathrm{x}$ & $\mathrm{x}$ & $\mathrm{x}$ & Risk register & 4.3 \\
\hline $\mathrm{x}$ & $\mathrm{x}$ & $\mathrm{x}$ & $\mathrm{x}$ & $\mathrm{x}$ & $\mathrm{x}$ & $\mathrm{x}$ & $\mathrm{x}$ & $\mathrm{x}$ & Design basis - requirements & 4.4 \\
\hline & & & $\mathrm{x}$ & $\mathrm{x}$ & $\mathrm{x}$ & $\mathrm{x}$ & $\mathrm{x}$ & $\mathrm{x}$ & Design basis - loads & 4.5 \\
\hline & & & $\mathrm{x}$ & $\mathrm{x}$ & $\mathrm{x}$ & $\mathrm{x}$ & $\mathrm{x}$ & $\mathrm{x}$ & Design description & 4.6 \\
\hline & & & $\mathrm{x}$ & $\mathrm{x}$ & $\mathrm{x}$ & $\mathrm{x}$ & $\mathrm{x}$ & $\mathrm{x}$ & Design analysis & 4.7 \\
\hline $\mathrm{x}$ & $\mathrm{x}$ & $\mathrm{x}$ & $\mathrm{x}$ & $\mathrm{x}$ & $\mathrm{x}$ & $\mathrm{x}$ & $\mathrm{x}$ & $\mathrm{x}$ & Define survivability targets \& strategies & 4.8 \\
\hline & & & & $\mathrm{x}$ & $\mathrm{x}$ & $\mathrm{x}$ & $\mathrm{x}$ & $\mathrm{x}$ & Define reliability \& maintainability targets \& strategies & 4.9 \\
\hline & & & $\mathrm{x}$ & $\mathrm{x}$ & $\mathrm{x}$ & $\mathrm{x}$ & $\mathrm{x}$ & $\mathrm{x}$ & Failure mode effects analysis (FMEA) & 4.10 \\
\hline $\mathrm{x}$ & $\mathrm{x}$ & $\mathrm{x}$ & $\mathrm{x}$ & $\mathrm{x}$ & $\mathrm{x}$ & $\mathrm{x}$ & $\mathrm{x}$ & $\mathrm{x}$ & Technology qualification plan & 4.11 \\
\hline $\mathrm{x}$ & $\mathrm{x}$ & $\mathrm{x}$ & $\mathrm{x}$ & $\mathrm{x}$ & $\mathrm{x}$ & $\mathrm{x}$ & $\mathrm{x}$ & $\mathrm{x}$ & Lessons learned & 4.12 \\
\hline
\end{tabular}

\subsection{Risk Management Plan}

The risk management plan defines how risk management is conducted throughout the development cycle. This MHK Risk Management Framework may provide the foundation for this risk management plan. This plan should be a living document to be continuously updated throughout the project with a focused update after each development cycle to integrate lessons learned (see Section 4.12).

\subsection{Project Plan}

The project plan describes how the project will be managed during the development cycle. This plan reduces negative risk impacts by considering and managing all the dynamic elements influencing the project. The level of detail for the project plan is commensurate with project complexity. The Project Management Institute's (PMI's) Project Management Body of Knowledge (PMBOK) is a useful reference when developing a project plan [4]. 


\subsection{Risk Register}

The risk register is a list of all uncertain events that could have a positive or negative impact on the MHK technology development. The risk register contains prioritized risks along with a response plan for each risk. A risk register should contain: risk categories, owners, severity assessments, frequency assessments, priorities, and response plans. Additional risk register details are contained in Section 5.

\subsection{Design Basis Requirements}

The design basis requirements state the conditions the MHK technology must be designed to meet. These requirements may include environmental conditions, design standards, controllability, and others. The design basis document should include requirements at each TRL development cycle.

The design basis should comply with the requirements within International Electrotechnical Commission (IEC) standards; specifically, IEC 62600-Part 2 (in committee draft format as of April 2015) [5]. Also, the design basis should consider the recommendations within European Marine Energy Centre's (EMEC's) design basis guideline [6] and the Det Norske Veritas (DNV) wave energy converter (WEC) design guideline [7]. The Electricity Supply Board International's (ESBI's) verification checklist may be helpful when developing TRL-specific requirements [8].

\subsection{Design Basis Loads}

The design basis loads is a subset of the design basis document describing the load conditions the design must meet. These load conditions consider dead, live, and accidental load conditions during all relevant life phases (manufacturing, transportation, assembly, deployment, commissioning, normal operation, extreme events, faults, maintenance, and decommissioning). The same references stated in Section 4.4 apply to this loads document.

\subsection{Design Description}

The design description documents the design and should be adequate to build, integrate, and test the design. The design documentation may include: model code, descriptive text, schematics, build prints, and/or an assembly design in the form of solid models or CAD models.

\subsection{Design Analysis}

The design analysis document presents analysis results for the design. These analyses are based on the requirements and loads from the design basis (Section 4.4 and 4.5). These analyses consider the structural response from load conditions and material resistance as appropriate. The analysis fidelity should be commensurate with failure risk.

\subsection{Define Survivability Targets and Strategies}

The MHK technology is expected to withstand the survivability targets, which may be a combination of environmental, operating, control, and fault conditions. The survivability strategy is the plan to achieve the survivability targets. These targets and strategies should be stated for each TRL and TPL development cycle. 
These targets and strategies should comply with the requirements within IEC 62600-Part 2 (in committee draft format as of April 2015) [5]. Sections 6 and 8 from the EMEC reliability, maintainability, and survivability guideline may be a useful reference when developing these targets and strategies [9].

\subsection{Define Reliability \& Maintainability Targets and Strategies}

Expected levels of reliability and maintainability for the MHK technology during a stated period are defined in this document. Reliability targets should be defined in terms of mean time between failures (MTBF) or mean time to repair (MTTR). Maintainability targets should be defined in terms of maintenance free operating periods (MFOP) or maintenance recovery period (MRP) [9]. The reliability and maintainability strategy is the plan to achieve these targets. The same references stated in Section 4.8 apply to this section.

\subsection{FMEA}

A failure mode effects analysis (FMEA) is a method of analyzing a system or component to obtain possible failure modes, effects, and causes [10]. Recommendations developed through the process of creating an FMEA may reduce failure risk to the system or component. FMEA results will contain a prioritized list of failure modes based on expected frequency and severity.

Appendix C contains references for FMEAs and other failure management tools. NREL anticipates releasing an FMEA framework for MHK technology development projects [11].

\subsection{Technology Qualification Plan}

The technology qualification plan outlines the steps to verify the technology has met the design requirements and targets. A wide range of tasks and activities, including tests, may be required to complete the technology qualification plan. Section 9 of DNV-RP-A203 provides recommendations for a technology qualification plan [12].

A test plan is a subset within and should describe the procedure for obtaining data to satisfy the technology qualification plan. All relevant IEC 62600 testing standards developed through the IEC TC 114 should be considered after they are published (not released in April 2015). The Equimar Protocols for assessing marine energy converters should be utilized when developing a test plan [13]. Also, a WEC test plan should consider the recommendations outlined in the International Towing Tank Conference (ITTC) Guideline for model test experiments [14] and the Ocean Energy Systems (OES) Guideline for testing systems [15]. All reported measurements should have an estimated uncertainty that complies with the Guide to the Expression of Uncertainty in Measurement (GUM) [16].

\subsection{Lessons Learned}

Lessons learned should be captured throughout the technology development process and at a formal debrief meeting following each TRL and TPL development cycle, per Figure 1. Section 6 contains details for collecting lessons learned. 


\section{Risk Register}

The risk register is a repository for current risk information that could influence project success as described in the following subsections. Each risk is analyzed in terms of the severity of its implications to the project and the expected frequency of its occurrence, which combined provides a basis for risk prioritization. The risk register contains a unique response plan describing how each risk will be managed. Monitoring and controlling risks involves detecting new risks and changes to existing risks. The ongoing process to monitor and control each risk should continuously occur throughout each technology development cycle displayed in Figure 1.

Figure 2 shows the risk register development processes along with the subsections describing these processes in further detail. A risk register template is provided in the referenced spreadsheet [17], which uses consistent terminology with this framework document.

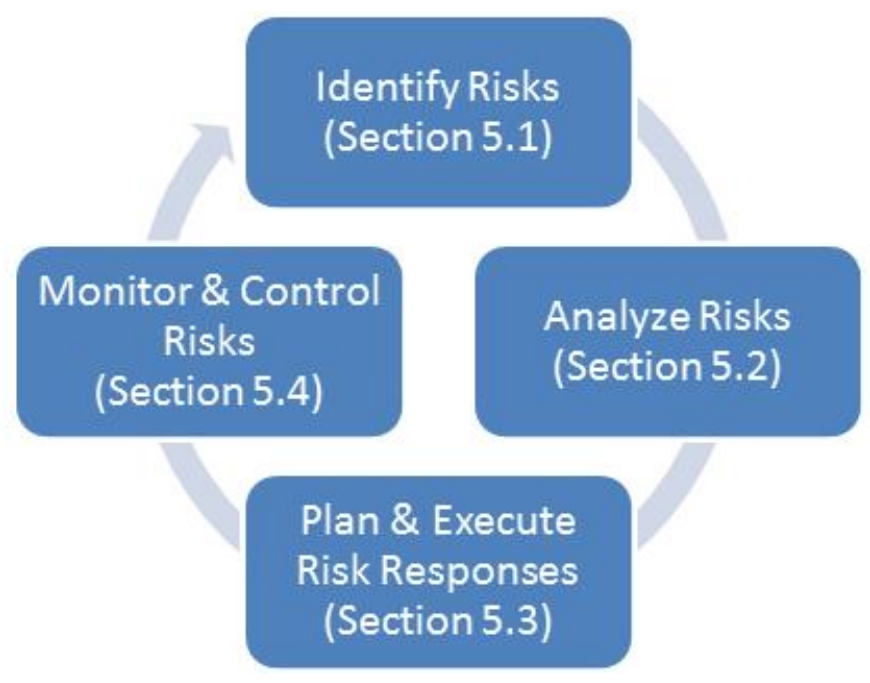

Figure 2. Risk register development processes

\subsection{Identify Risks}

The purpose of risk identification is to identify uncertainties that may impact the MHK technology development. These uncertainties may be from the particular application of a common design or from the pursuit of unproven design concepts. All uncertain project elements are possible inputs to the risk identification process. International standards may be used with or without adaptation to help identify risks. Risk identification facilitates the FMEA process by identifying inputs not contained within applicable standards. It is important to consider risks from other projects and industries that may be relevant to the MHK technology development.

Risk identification involves categorically listing risks with associated risk owners. The process output is the creation and maintenance of a comprehensive risk registry. This registry will be continuously updated throughout the technology development project as new risks are identified or changes occur to existing risks. The following subsections describe the risk identification process. 


\subsubsection{Risk Breakdown Structure}

The risk breakdown structure (RBS) is a hierarchical breakdown of all project risks into common categories. An RBS is useful for the complete identification of risks.

The cost breakdown structure (CBS) for the MHK project is a hierarchical breakdown of all project costs into common categories. The CBS is useful for the complete identification and decomposition of cost and associated financial risk. The identified risks within the CBS may apply to multiple RBS levels.

The example RBS in Table 4 may be a helpful starting point to develop a project specific RBS. Some of the Table 4 material was copied from references [18] [19]. Table 5 contains example MHK risks mapped to RBS levels in Table 4-these risks are from the DNV WEC design guideline [7]. The Appendix B from DNV-RP-A203 contains a cause-of-failure checklist that may be used when considering possible project risks [12].

Table 4. Example RBS [18] [19]

\begin{tabular}{|c|c|c|}
\hline RBS Level 0 & RBS Level 1 & RBS Level 2 \\
\hline \multirow[t]{22}{*}{ All sources of project risk } & \multirow[t]{11}{*}{ 1. Technical Risk } & 1.1 Scope definition \\
\hline & & 1.2 Requirements definition \\
\hline & & 1.3 Estimates, assumptions, constraints \\
\hline & & 1.4 Technical processes \\
\hline & & 1.5 Technology \\
\hline & & 1.6 Technical interfaces \\
\hline & & 1.7 System reliability \\
\hline & & 1.8 Performance \\
\hline & & 1.9 Safety \\
\hline & & 1.10 Security \\
\hline & & 1.11 TBD \\
\hline & \multirow[t]{11}{*}{ 2. Management Risk } & 2.1 Project management \\
\hline & & 2.2 Program/Portfolio management \\
\hline & & 2.3 Operations management \\
\hline & & 2.4 Organization \\
\hline & & 2.5 Human resourcing \\
\hline & & 2.6 Funding \\
\hline & & 2.7 Communication \\
\hline & & 2.8 Information \\
\hline & & 2.9 Quality \\
\hline & & 2.10 Reputation \\
\hline & & 2.11 TBD \\
\hline
\end{tabular}




\begin{tabular}{|c|c|c|}
\hline RBS Level 0 & RBS Level 1 & RBS Level 2 \\
\hline & \multirow[t]{8}{*}{ 3. Commercial Risk } & 3.1 Contractual terms and conditions \\
\hline & & 3.2 Internal procurement \\
\hline & & 3.3 Suppliers and vendors \\
\hline & & 3.4 Subcontracts \\
\hline & & 3.5 Client/customer stability \\
\hline & & 3.6 Partnerships and joint ventures \\
\hline & & 3.7 Levelized cost of energy (LCOE) \\
\hline & & $3.8 \mathrm{TBD}$ \\
\hline & \multirow[t]{10}{*}{ 4. External Risk } & 4.1 Legislation \\
\hline & & 4.2 Exchange rates \\
\hline & & 4.3 Site/facilities \\
\hline & & 4.4 Environmental/weather \\
\hline & & 4.5 Competition \\
\hline & & 4.6 Regulatory \\
\hline & & 4.7 Political \\
\hline & & 4.8 Force majeure \\
\hline & & 4.9 External stakeholder \\
\hline & & $4.10 \mathrm{TBD}$ \\
\hline
\end{tabular}

Table 5. Example Risks Mapped to RBS [7]

\begin{tabular}{|l|l|}
\hline Risk Name & Table 4 RBS Level \\
\hline Anchor/foundation failure & 1.7 \\
\hline Mooring failure & 1.7 \\
\hline Breach of water integrity of compartments or equipment & 1.6 \\
\hline Stability failure & 1.7 \\
\hline Collision risks & 4.8 or 4.9 \\
\hline Interference with commercial and recreational marine activities & 4.9 \\
\hline Structural failure & 1.7 \\
\hline Fishing gear impact & 1.3 \\
\hline Personnel risks to operators and to the general public & 1.9 \\
\hline Pressure containment failure from hydraulic or pneumatic systems & 1.7 \\
\hline Electrical failures and shore connector failures & 1.7 \\
\hline Seismic events & 4.4 or 4.8 \\
\hline Fires & 4.8 \\
\hline Interference floating debris with device & 1.7 \\
\hline
\end{tabular}




\subsubsection{Technology Life Phases}

Technology life phases are sequential stages of technology development that occur from concept to retirement. The life phases at a high level within each TRL and TPL cycle may include:

- Specification

- Design

- Manufacturing

- Transportation

- Assembly and commissioning

- Operation:

$\begin{array}{ll}\circ & \text { Normal power production } \\ \circ & \text { Extreme events } \\ \circ & \text { Faults } \\ \circ & \text { Maintenance } \\ \circ & \text { Repair }\end{array}$

- Decommissioning

Each TRL and TPL development cycle will have a set of technology life phases. As possible, the user should determine the appropriate technology life phases within each TRL and TPL development cycle, and assign risks to one, multiple, or all life phases.

\subsubsection{Risk Owner}

An owner is assigned to each risk within the risk registry with risk management responsibility throughout the project development cycle(s). Risk management responsibilities include monitoring and controlling the risks and implementing the risk response strategies. Monitoring risks includes noting any changes that may warrant an update to the risk registry.

\subsection{Analyze Risks}

Quantitative risk analysis is critical to the overall risk management plan. All risks must be characterized in terms of 1) type (personnel, property and environment), 2) severity of consequence (minor-to-severe), and 3) the frequency of occurrence. Based on the characterization, each risk can be prioritized and managed. The quantified risk impacts may guide the team when making technology development decisions.

A probability and impact matrix [4] is the tool described in Section 5.2 (same as a consequence/probability matrix [20]). This tool was chosen based on its ease of use and its application to a diverse set of project risk scenarios. A weakness of this tool is the subjective nature of assigning risk frequency and severity levels [20]. The user is encouraged to utilize additional risk management tools that may be more appropriate for each unique situation.

The IEC/ISO 31010 standard describes many different tools and techniques to analyze risks, including: consequence/probability matrix, fault tree analysis, scenario analysis, cost/benefit 
analysis, root cause analysis, and many others [20]. The PMI's PMBOK describes multiple risk analysis methods [4]; their risk management standard provides even greater details on risk analysis tools and techniques [18].

\subsubsection{Risk Types and Severity}

Risk types (TYP) are categorized by the areas primarily impacted by risk occurrence. These types, as shown in Table 6, include: safety, cost, time, scope, quality, environment, and regulation. A risk severity value (SEV) is used to quantify the severity of the outcome should that risk occur. In Table 6 , the risk increases in severity from 0 , no severity level, to 5 , lethal. The severity quantification combined with its frequency will enable risk prioritization.

Table 6 contains a risk severity and risk type matrix that provides quantitative measures for each combination of TYP and SEV. The Table 6 information is intended to be a starting point that is modified for each unique development project. A given risk could be assessed at every risk type or at the perceived most important one(s), provided the impacts to the other risk types are maintained at acceptable levels when controlling the risk. For example, a given risk could be analyzed in terms of its impacts on safety and/or cost and/or time and/or other risk types.

Positive risks can be tracked with a negative severity parameter and opposite definitions of those in Table 6 (i.e. a "-2 time risk" would advance_-versus delay_the schedule by 1 week to 1 month). 
Table 6. Example Risk Types and Severity Definitions [7]

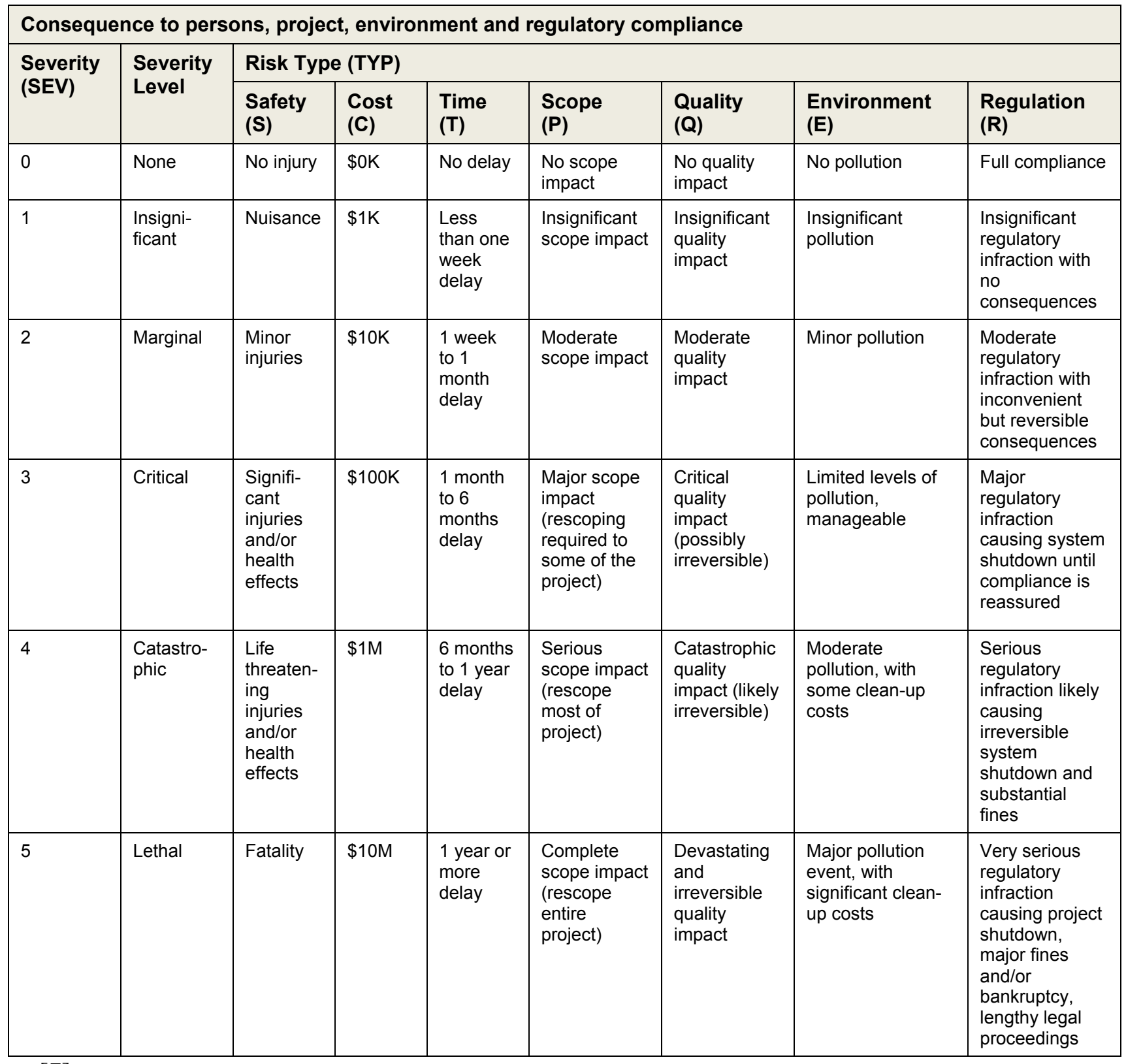

[7]

\subsubsection{Risk Frequency}

The frequency of risk (FRQ) value quantifies the probability of a risk occurring during a given period. Table 7 contains suggested definitions for a relative frequency scale from zero to five, with an analyzed period of one year. Typically, the assigned frequency is based on the expert judgment of the user in combination with historical data when available. Also, published reliability data from similar industries such as offshore oil and gas should be considered as appropriate [21]. 
Table 7. Risk Frequency Definitions

\begin{tabular}{|l|l|}
\hline $\begin{array}{l}\text { Frequency } \\
\text { (FRQ) }\end{array}$ & $\begin{array}{l}\text { Estimated Probability }(\mathrm{p}) \text { of Occurrence } \\
\text { During One Year }(\% \text { per year) }\end{array}$ \\
\hline 0 & $\mathrm{p}<0.01 \%$ \\
\hline 1 & $0.01 \%<\mathrm{p}<0.1 \%$ \\
\hline 2 & $0.1 \%<\mathrm{p}<1 \%$ \\
\hline 3 & $1 \%<\mathrm{p}<10 \%$ \\
\hline 4 & $10 \%<\mathrm{p}<50 \%$ \\
\hline 5 & $\mathrm{p}>50 \%$ \\
\hline
\end{tabular}

\subsubsection{Risk Priority Number}

The risk priority number (RPN) is derived from a probability and impact matrix and it provides a measure of risk priority. The RPN is the product of the risk frequency and severity values. The RPN is segregated into low, medium, and high risk zones, as shown in Figure 3. Generally, a low RPN should be targeted for all negative risks, a medium RPN may be acceptable under certain circumstances, and a high RPN is unacceptable. The user should define acceptability thresholds that are specific to their project.

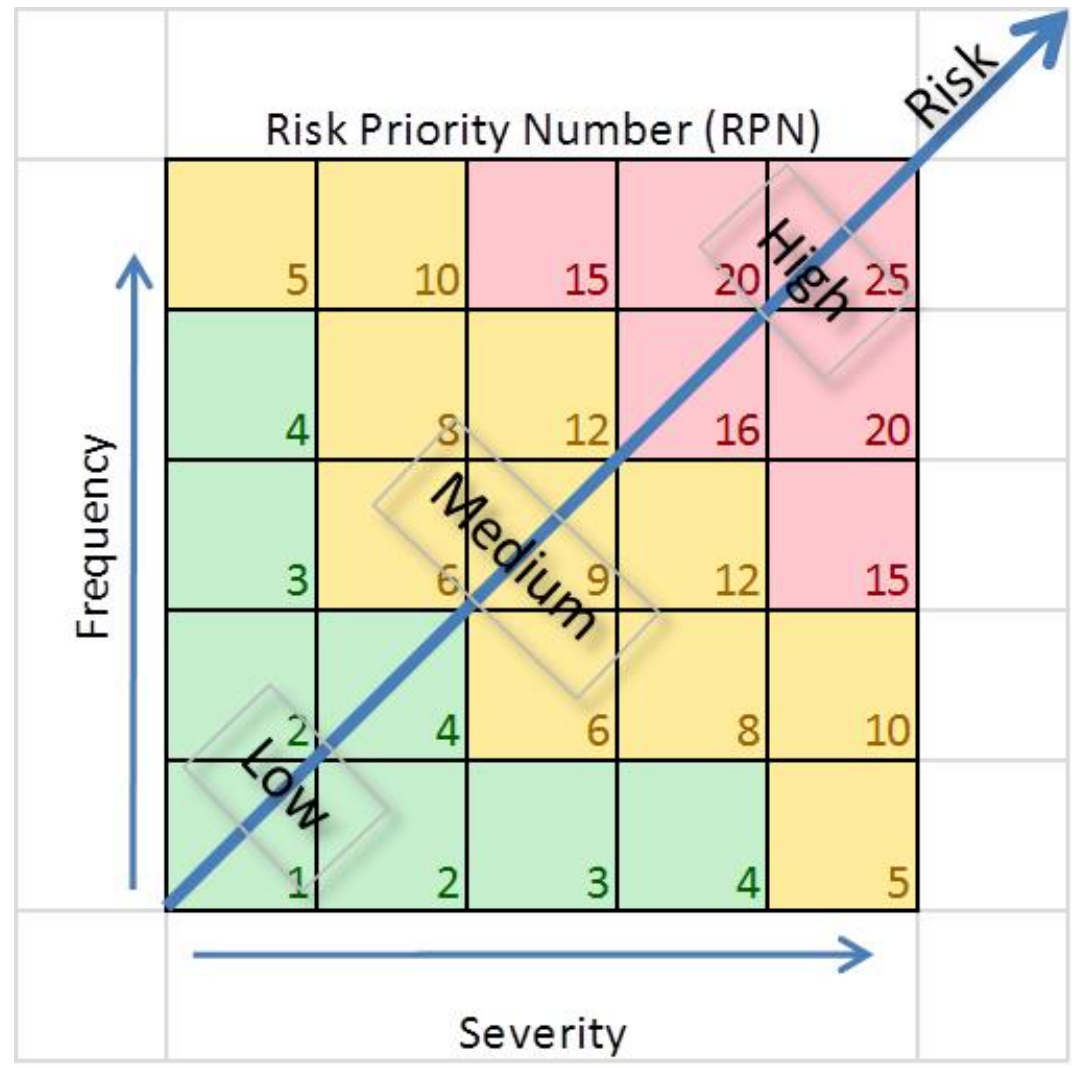

Figure 3. Risk priority number [7] 


\subsection{Plan and Execute Risk Responses}

A risk response plan describes how each unique risk will be managed. A risk response plan is important because each risk may have interdependencies with other project functions. The implications of each risk occurring is considered when developing the response plan. The risk register is structured to contain information described in the following subsections for each identified risk.

\subsubsection{Risk Response Strategies}

The risk response strategy describes the type of response to each risk. The response strategy for each risk is structured using the Table 8 strategy types combined with a unique description. An effective response strategy requires budget and schedule authorization to implement the response for each risk. The response may address the root cause and/or the effect of the risk and should consider input from - and are communicated to —all relevant project stakeholders [18].

The four strategy types for negative risk (threats) responses include: avoid, transfer, mitigate, and accept (Table 8). The avoid strategy is usually preferred because the risk will not occur and impact the project. The transfer strategy may be used if an important risk cannot be avoided or mitigated, and there is a third party willing to accept the risk. The mitigate strategy may be the most common strategy where efforts are made to reduce the probability and/or impact of the risk. An accept strategy may be chosen because the risk impacts are negligible and no actions are needed. Alternatively, the accept strategy may be conditional if a process is started under controlled conditions to verify risk assumptions, or it may be temporary if data is obtained under controlled conditions for future risk reassessment.

The positive risk (opportunity) response strategies are complementary to the associated negative strategies (Table 8). Positive risk response strategies aim to maximize impact from uncertain opportunities.

Table 8. Risk Response Strategies [18]

\begin{tabular}{|l|l|l|l|}
\hline \multicolumn{2}{|l|}{ Negative Risk (Threats) Responses } & \multicolumn{2}{l|}{ Positive Risk (Opportunity) Responses } \\
\hline $\begin{array}{l}\text { Strategy } \\
\text { Type }\end{array}$ & Strategy Description & $\begin{array}{l}\text { Strategy } \\
\text { Type }\end{array}$ & Strategy Description \\
\hline Avoid & $\begin{array}{l}\text { Ensuring the risk cannot occur or will } \\
\text { have no impact on the project (e.g., } \\
\text { removing high-risk equipment from the } \\
\text { system) }\end{array}$ & Exploit & $\begin{array}{l}\text { Ensuring the opportunity will occur and the } \\
\text { project will benefit from it }\end{array}$ \\
\hline Transfer & $\begin{array}{l}\text { Transferring the risk to a third party (e.g., } \\
\text { insurance company) }\end{array}$ & Share & Sharing the opportunity with another party \\
\hline Mitigate & $\begin{array}{l}\text { Reducing the probability and/or } \\
\text { consequence of a risk }\end{array}$ & Enhance & $\begin{array}{l}\text { Increasing the probability and/or } \\
\text { consequence of an opportunity }\end{array}$ \\
\hline Accept & $\begin{array}{l}\text { Accepting the risk without pursuing any } \\
\text { of the other strategies-contingency } \\
\text { plans may be developed if the risk occurs }\end{array}$ & Accept & $\begin{array}{l}\text { Accepting the opportunity without pursuing } \\
\text { any of the other strategies }\end{array}$ \\
\hline
\end{tabular}




\subsubsection{Risk Response Timing and Triggers}

The timing and trigger conditions clearly identify when a risk response is commenced. Timing may simply be a schedule for implementing the risk response (e.g., risk response strategy will be implemented on June 24). Alternatively, the risk response may be triggered by conditions - other than the risk becoming reality (e.g., implement response if project is over budget by more than $10 \%$ at any quarterly review).

\subsubsection{Residual Risk after Risk Response}

The residual risk quantifies the expected results from the risk response, which includes the residual risk RPN and a description of the anticipated results. The residual risk RPN is calculated using the same methods as the baseline risk (see Section 5.2). The residual risk description includes the expected primary outcome from the risk response (i.e., the expected results by implementing the response strategy).

From Table 8, for an avoid strategy, the residual risk severity and/or frequency is zero. For a transfer strategy, the residual risk severity may be less because a third party is sharing responsibility, but the frequency will remain unchanged. For a mitigate strategy, the residual risk severity and/or frequency will be less. For an accept strategy, the residual risk severity and frequency will be the same as the baseline risk condition.

\subsubsection{Secondary Risks Resulting from Risk Response}

Secondary risks are those risks caused by implementing a risk response strategy to the primary risk. It is important to identify and analyze secondary risks to ensure the risk response is worth pursuing. The risk register includes a field identifying secondary risks within each primary risk; each secondary risk is analyzed as a separate risk item within the risk register using the Section 5.2 methods, as appropriate.

\subsubsection{Contingency Plan}

The contingency plan describes the actions to take if a risk event occurs-when the risk response strategy was not successful in preventing the negative risk event from occurring (or conversely, it was successful in realizing the positive risk event). Each risk within the risk register contains a unique contingency plan.

For example, there may be an estimated 5\% probability that a critical regulatory permit will not be issued for a project. The contingency plan lists the action to be taken if this permit is not issued. In contrast, the risk response strategy may be the actions that minimize the impact or frequency of the permit not being issued.

\subsection{Monitor and Control Risks}

Monitoring and controlling risks is a process that occurs continuously throughout each technology development cycle (Figure 1). Monitoring risks includes 1) detecting any differences between the current project conditions and the risk register information and 2) identification of new risks not contained within the risk register. Controlling risks includes the execution of risk responses by the risk owner according to the risk response timing and trigger conditions. The risk register is updated with new information according to the cycle in Figure 2. 


\section{Lessons Learned}

Collecting lessons learned is an important part of a comprehensive risk management plan because it promotes organizational learning that may reduce the frequency and/or severity of future negative risks. The lessons learned provide input to improve the risk management plan (Section 4.1) as shown in Figure 1. Also, it may help foster future successes in areas where positive outcomes were realized.

Lessons learned may be documented using separate tables; one for issues (problems) and one for successes. The issue table should describe each issue along with its impact and contain recommendations for improvement. The success table should describe each success, factors supporting the success, and its impact. Action items are assigned to implement changes based on each lesson learned.

Lessons learned are best captured when they are noted by a team member and a formal debrief meeting with all team members should conclude each technology development cycle. The debrief meeting allows the team to stop and examine what occurred during the previous development cycle. The risk register is updated, as appropriate, from lessons-learned information.

It is important to share some lessons learned with the broader MHK industry. Sharing lessons learned - particularly related to safety - will foster overall success for the industry without compromising competitiveness.

The following are suggested templates for documenting lessons learned during or after each development cycle. Table 9 is a suggested template to document issues and Table 10 is a suggested template to document successes. Mock data are shown in these tables to demonstrate its potential use; red font is used to highlight action items. The Vanderbilt Guide contains additional recommendations for collecting lessons learned [22].

The following are some possible questions to consider when conducting a project debrief:

- What worked well—or didn’t work well—during this development cycle?

- What worked well—or didn't work well—for the project team?

- What needs to be done differently?

- What project circumstances were not anticipated?

- How can we improve our technology development process? 
Table 9. Template for Lessons-Learned Issues (Mock Data Shown)

\begin{tabular}{|c|c|c|c|c|c|c|c|c|}
\hline Date & $\begin{array}{l}\text { Project } \\
\text { Cycle }\end{array}$ & $\begin{array}{l}\text { Issue } \\
\text { category }\end{array}$ & $\begin{array}{l}\text { Issue } \\
\text { name }\end{array}$ & $\begin{array}{l}\text { Issue } \\
\text { description } \\
\text { (possible } \\
\text { cause) }\end{array}$ & Impact & $\begin{array}{l}\text { Recommendation } \\
\text { for improvement } \\
\text { (action items) }\end{array}$ & $\begin{array}{l}\text { Action } \\
\text { item } \\
\text { initials }\end{array}$ & $\begin{array}{l}\text { Follow-up } \\
\text { actions } \\
\text { completed }\end{array}$ \\
\hline 140712 & $\begin{array}{l}\text { TRL } 5 \text {, } \\
\text { TPL } 7\end{array}$ & Scope & Bolt torque & $\begin{array}{l}\text { It was uncertain } \\
\text { if bolts on } \\
\text { generator were } \\
\text { torqued } \\
\text { according to the } \\
\text { specification }\end{array}$ & $\begin{array}{l}\text { Potential } \\
\text { damage to } \\
\text { generator if } \\
\text { operated } \\
\text { without proper } \\
\text { torque; } \\
\text { required } \\
\text { potentially } \\
\text { unnecessary } \\
\text { retorque } \\
\text { operation }\end{array}$ & $\begin{array}{l}\text { Develop a checklist for } \\
\text { technician to initial } \\
\text { when torque operation } \\
\text { completed }\end{array}$ & MD & $\begin{array}{l}\text { Checklist } \\
\text { developed for } \\
\text { next test } \\
\text { phase }\end{array}$ \\
\hline 140712 & $\begin{array}{l}\text { TRL } 5 \text {, } \\
\text { TPL } 7\end{array}$ & Quality & $\begin{array}{l}\text { Missing test } \\
\text { records }\end{array}$ & $\begin{array}{l}\text { During testing, } \\
\text { notes were not } \\
\text { regularly taken } \\
\text { by test } \\
\text { personnel }\end{array}$ & $\begin{array}{l}\text { Unable to } \\
\text { reconstruct the } \\
\text { actual test } \\
\text { events }\end{array}$ & $\begin{array}{l}\text { Develop a dedicated } \\
\text { logbook for each test } \\
\text { campaign; develop } \\
\text { process for capturing } \\
\text { test events in logbook }\end{array}$ & RB & $\begin{array}{l}\text { Logbooks } \\
\text { available for } \\
\text { each test; } \\
\text { procedure } \\
\text { developed for } \\
\text { logbook } \\
\text { usage }\end{array}$ \\
\hline 140712 & $\begin{array}{l}\text { TRL } 5 \\
\text { TPL } 7\end{array}$ & $\begin{array}{l}\text { Human } \\
\text { resource }\end{array}$ & $\begin{array}{l}\text { Staff } \\
\text { availability }\end{array}$ & $\begin{array}{l}\text { Staff availability } \\
\text { was unknown in } \\
\text { advance of } \\
\text { absence }\end{array}$ & $\begin{array}{l}\text { Testing was } \\
\text { delayed due to } \\
\text { key staff being } \\
\text { unavailable }\end{array}$ & $\begin{array}{l}\text { Develop a staff } \\
\text { calendar indicating } \\
\text { upcoming staff } \\
\text { vacations and other out } \\
\text { of office events }\end{array}$ & DS & TBD \\
\hline
\end{tabular}

Table 10. Template for Lessons-Learned Successes (Mock Data Shown)

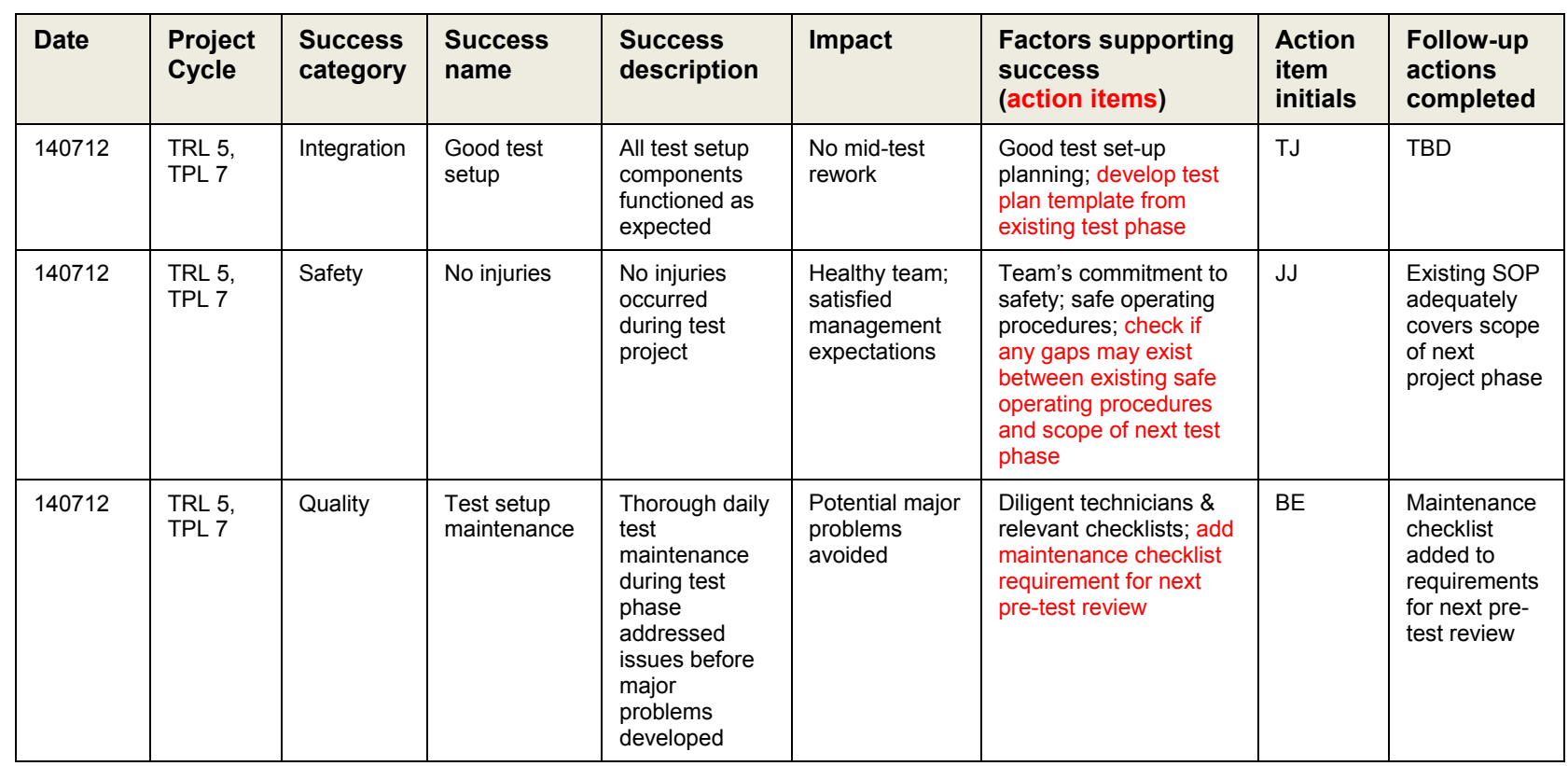




\subsection{Definitions for Terms Used Within the Fields from Table 9 and Table 10:}

Date - the date when the problem/success was documented.

Project Cycle - the project cycle based on TRL and TPL designations from Figure 1.

Issue/Success Category - the category assigned for each problem/success. A suggested categorization scheme is to use safety and the ten PMBOK knowledge areas [4]. Alternatively, the seven risk type categories from Table 6 may be used to categorize the lessons learned. Although each issue/success may fit within more than one category, choose one category with the greatest impact.

Issue/Success Name - the unique name given to the identified issue/success.

Issue Description (Possible Cause) - the description of the issue along with any possible causes.

Success Description - the description of the success.

Impact - the impact on the project or team as a result of the specific issue/success.

Recommendation for Improvement (Action Items) - recommendations that may reduce the frequency of reoccurrence or severity of the issue. Action items should be listed to implement these changes. Action items are shown in red font within Table 9 to highlight items requiring follow-up.

Factors Supporting Success (Action Items) - the positive factors that contributed toward the successful outcome. Action items should be listed if activities can be implemented that promote these factors to reoccur in the future. Action items are shown in red font within Table 10 to highlight items requiring follow-up.

Action Item Initials - the person responsible for executing the action item.

Follow-up Actions Completed - the follow-up actions taken based on the assigned action items. 


\section{References}

[1] DOE, "Technology Readiness Assessment Guide, DOE G 413.3-4A," U.S. Department of Energy, Washington D.C., 2011, Accessed October 22, 2014:

https://www.directives.doe.gov/directives-documents/400-series/0413.3-EGuide04a/@@download/file.

[2] Weber, J. W.; R. Costello; and J. Ringwood, "WEC Technology Performance Levels (TPLs) - Metric for Successful Development of Economic WEC Technology," in Tenth European Wave and Tidal Energy Conference (EWTEC), Aalborg, 2013.

[3] Weber, J. W. "WEC Technology Readiness and Performance Matrix - finding the best research technology development trajectory," in 4th International Conference on Ocean Energy (ICOE), Dublin, 2012, Accessed on January 21, 2015: http://www.researchgate.net/publication/233810908_WEC_Technology_Readiness_and_P erformance_Matrix_finding_the_best_research_technology_development_trajectory.

[4] PMI, A Guide to the Project Management Body of Knowledge (PMBOK), 5th edition, Newtown Square: Project Management Institute (PMI), 2013.

[5] IEC, 62600-2, Design requirements for marine energy systems--Part 2, TBD.

[6] EMEC, Guidelines for Design Basis of Marine Energy Conversion Systems, EMEC, 2009, Accessed October 22, 2014: http://www.emec.org.uk/?wpfb_dl=40.

[7] DNV, Guidelines on Design and Operation of Wave Energy Converters, DNV, 2005, Accessed on October 22, 2014: http://www.gl-group.com/pdf/WECguideline_tcm4270406.pdf.

[8] Westwave, "Appendix 2 Technology Readiness Levels for Supply Chain Study for WestWave, ESBloe-WAV-11-027," Dublin, undated, Accessed on May 9, 2014: http://www.westwave.ie/wp-content/uploads/downloads/2011/12/Appendix-2.pdf.

[9] EMEC, Guidelines for Reliability, Maintainability and Survivability of Marine Energy Conversion Systems, BSI, 2009, Accessed on October 22, 2014: http://www.emec.org.uk/?wpfb_dl=41.

[10] IEC, IEC 60812, Analysis Techniques for System Reliability - Procedure for Failure Mode and Effects Analysis (FMEA), Brussels: CENELEC, 2006.

[11] NREL, "FMEA Framework," Golden, Colorado. unpublished.

[12] DNV, DNV-RP-A203, Technology Qualification, DNV, 2013, Accessed on October 22, 2014: https://exchange.dnv.com/publishing/codes/docs/2013-07/RP-A203.pdf.

[13] EquiMar, Protocols for the Equitable Assessment of Marine Energy Converters, Institute for Energy Systems, School of Engineering, The University of Edinburgh, 2011, Accessed on October 22, 2014: http://www.ocean-energysystems.org/documents/65960_protocols_a4_downlaod.pdf/.

[14] ITTC, 7.5-02-07-03.7, Wave Energy Converter Model Test Experiments, ITTC, 2011, Accessed on October 22, 2014: http://ittc.sname.org/CD 2011/pdf Procedures 2011/7.5-0207-03.7.pdf. 
[15] Holmes, B. and K. Nielsen, OES IA Document No: T02-2.1, Guidelines for the Development \& Testing of Wave Energy Systems Final Technical Report, IEA Oceans, 2010, Accessed on October 22, 2014: http://www.ocean-energysystems.org/documents/39874_report_02_2.1_a_.pdf/.

[16] Joint Committee for Guides in Metrology (JCGM), "(GUM) Evaluation of measurement data--Guide to the expression of uncertainty in measurement," Joint Committee for Guides in Metrology, September 2008. [Online]. Available: http://www.bipm.org/utils/common/documents/jcgm/JCGM_100_2008_E.pdf. [Accessed 16 April 2015].

[17] NREL, MHK Risk Register Template,version: September 23, 2015 http://www.nrel.gov/docs/fy15osti/63258 template.xlsx, Golden, Colorado. 2015.

[18] PMI, Practice Standard for Project Risk Management, Newtown Square: Project Management Institute (PMI), 2009.

[19] Hillson, D. and P. Simon, ATOM Templates \& Examples, Accessed May 12, 2014: http://www.atom-risk.com/templates.html, 2007.

[20] IEC/ISO, IEC/ISO 31010, Risk Management - Risk Assessment Techniques, Geneva: IEC, 2009.

[21] Offshore Reliability Data (OREDA), Offshore REliability DAta, Hovik: DNV, 2009, Accessed October 23, 2014: www.oreda.com.

[22] Salem-Schatz, S.; D. Ordin; and B. Mittman, Guide to the After Action Review, 2010, Accessed on October 23, 2014:

http://as.vanderbilt.edu/overview/faculty/facultycouncil/archive/sitemason.vanderbilt.edu/f iles/cHpJCw/Guide\%20to\%20the\%20After\%20Action\%20Review.pdf.

[23] IEC, IEC/TS 62600-1, Marine Energy - Wave, Tidal, and Other Water Current Converters - Part 1: Terminology, Geneva: IEC, 2011.

[24] ISO, ISO Guide 73, Risk Management - Vocabulary, Geneva: ISO, 2009.

[25] DNV, DNV-OSS-312, Certification of Tidal and Wave Energy Converters, DNV, 2008, Accessed on October 22, 2014: https://exchange.dnv.com/publishing/Codes/download.asp?url=2008-10/oss-312.pdf.

[26] ISO, ISO 31000, Risk Management - Priciples and Guidelines, Geneva: ISO, 2009.

[27] DNV, DNV-RP-H101, Risk Management in Marine - And Subsea Operations, DNV, 2003, Accessed on October 22, 2014: https://exchange.dnv.com/publishing/codes/download.asp?url=2003-01/rp-h101.pdf.

[28] American Bureau of Shipping (ABS), Guidance Notes on Risk Assessment Applications for the Marine and Offshore Oil and Gas Industries, ABS, 2000, Accessed on October 22, 2014: http://ww2.eagle.org/content/dam/eagle/rules-andguides/current/other/97_riskassessapplmarineandoffshoreoandg/pub97_riskassesment.pdf.

[29] API, API Recommended Practice 17N, Recommended Practice for Subsea Production System Reliability and Technical Risk Management, Washington D.C.: API, 2009.

[30] DNV, "Marine Risk Assessment 2001/063," HSE, London, 2001, Accessed on October 22, 2014: http://www.hse.gov.uk/research/otopdf/2001/oto01063.pdf. 
[31] DNV, DNV-RP-D102, Failure Mode and Effect Analysis (FMEA) of Redundant Systems, DNV, 2012, Accessed on October 22, 2014:

https://exchange.dnv.com/publishing/codes/download.asp?url=2012-01/rp-d102.pdf.

[32] International Marine Contractors Association (IMCA), IMCA M166, Guidance on Failure Modes \& Effects Analyses (FMEAs), IMCA, 2002, Accessed on October 22, 2014: http://www.imca-int.com/media/73361/imcam166.pdf.

[33] DOD, MIL-STD-1629A, Procedures for Performing a Failure Mode, Effects and Criticality Analysis, DOD, 1980, Accessed on October 22, 2014:

http://assistdoc1.dla.mil/Analyse/ImageRedirector.aspx?token=59770.37027.

[34] IEC, IEC 61025, Fault Tree Analysis (FTA), Geneva: IEC, 2006.

[35] IEC, IEC 61078, Analysis Techniques for Dependability - Reliability Block Diagram and Boolean Methods, Geneva: IEC, 2006.

[36] IEC, IEC 62502, Analysis Techniques for Dependability - Event Tree Analysis (ETA), Geneva: IEC, 2010.

[37] DNV, DNV-OS-C501, Composite Components, DNV, 2013, Accessed on October 22, 2014: https://exchange.dnv.com/publishing/codes/download. asp?url=2013-11/os-c501.pdf.

[38] IEC, 62600-10, Marine Energy - Wave, Tidal and Other Water Current Converters - Part 10: Assessment of Mooring System for Marine Energy Converters (MECs), IEC, 2013 (CD).

[39] ABS, "Guide For Fatigue Assessment of Offshore Structures," ABS, Houston, 2003, Accessed on October 22, 2014: http://ww2.eagle.org/content/dam/eagle/rules-andguides/current/offshore/115_fatigueassessmentofoffshorestructures/FAOS.pdf.

[40] Germanischer Lloyd (GL), "Rules for Classification and Construction, Industrial Services, 6 Offshore Technology, 4 Structural Design," GL, Hamburg, 2007, Accessed on October 22, 2014: http://www.gl-group.com/infoServices/rules/pdfs/gl_iv-6-4_e.pdf.

[41] ISO, ISO 12100, Safety of Machinery - General Principles for Design - Risk Assessment and Risk Reduction, Brussels: CEN, 2010.

[42] National Aeronautics and Space Administration (NASA), Definition of Technology Readiness Levels, NASA, Accessed on November 10, 2014: http://esto.nasa.gov/files/trl_definitions.pdf.

[43] DNV, DNV-OS-D201, Electrical Installations, DNV, 2013, Accessed on October 22, 2014: http://exchange.dnv.com/publishing/codes/docs/2013-10/OS-D201.pdf.

[44] Standing, R. Review of the risk assessment of buoyancy loss (RABL) project, Norwich: HSE (UK Health \& Safety Executive), 2003, Accessed on November 10, 2014: http://www.hse.gov.uk/research/rrpdf/rr143.pdf.

[45] Turnock, S. R.; R. Nicholls-Lee; R. Wood; and J. A. Wharton, Tidal Turbines that Survive, University of Southampton, School Engineering Sciences, Accessed on November 10, 2014: http://eprints.soton.ac.uk/66727/1/Gold_platedv4.pdf.

[46] Hurley, S. "Reliability-Based Fatigue Design of Marine Current Turbine Rotor Blades," Florida Atlantic University (Masters Thesis), Boca Raton, 2011, Accessed on November 10, 2014: http://snmrec.fau.edu/sites/default/files/research/theses/DT-11-217.pdf. 
[47] McCann, G. "Tidal current turbine fatigue loading sensitivity to waves and turbulence - a parametric study," in 7th European Wave and Tidal Energy Conference, Porto, 2007, Accessed on November 10, 2014: http://www.gl-

garradhassan.com/assets/downloads/Tidal_Current_Turbine_Fatigue_Loading_Sensitivity _to_Waves_and_Turbulence.pdf.

[48] Davies, P.; G. Germain; G. Benoit; A. Boisseau; and D. Perreau, "Evaluation of the durability of composite tidal turbine blades," in Royal Society of London, London, 2012, Accessed on November 10, 2014: http://archimer.ifremer.fr/doc/00079/19053/20068.pdf.

[49] DNV, DNV-RP-C205, Environmental Conditions and Environmental Loads, DNV, 2010, Accessed on November 11, 2014:

https://exchange.dnv.com/publishing/codes/download.asp?url=2010-10/rp-c205.pdf. 


\section{Appendix A-Risk Management Checklist for DOE Funding Opportunity Announcement (FOA) Applications}

Effective risk management is an important precursor to a successful project. Demonstrating risk management according to the MHK Risk Management Framework may be required of all DOE FOA awardees. All FOA applicants should review and understand this framework. The FOA awardee may use their existing risk management procedures if they meet or exceed the basic requirements outlined in the MHK Risk Management Framework. As part of the FOA application, the following items should be addressed within the FOA proposal:

$\checkmark$ Provide a brief description of the system and/or constituent components to be developed within this FOA project

$\checkmark$ Describe your risk management strategy with reference to each of the following subsystems and project metrics:

○ Loss of functionality to:

- power take-off (PTO) or rotor assembly

- electrical systems

- mechanical systems

- wear items (seals, bearings, etc.)

- structure (break, fatigue, etc.)

- mooring or foundation

- control system

- data/monitoring system

- Loss of device

- Reduced power production compared to expectations/predictions

- Low availability

- Incomplete data amount collected during testing

- Delay in deployment or commissioning

- Breach of safety requirements

$\checkmark$ Will you use the MHK Risk Management Framework or other risk management plan? If other, then provide adequate documentation of this plan that includes detail equivalent to the MHK Risk Management Framework (i.e., it must contain structured reviews [design, test readiness, and risk] and activities described in Table 3).

$\checkmark$ Currently, what is the technology TRL and TPL (pre-FOA)?

$\checkmark$ What are the expected TRLs and TPLs at funding conclusion?

$\checkmark$ What are proposed TRL and TPL steps to take during FOA period of performance? (e.g., starting at TRL-1 and TPL-1, then TRL-3 and TPL-3, etc.)

$\checkmark$ What components or subsystems, if any, will be developed and tested in parallel with the overall system? How does this de-risk the overall system test?

$\checkmark$ Describe the preliminary survivability targets and the strategy to obtain these targets, per Section 4.8 of this framework. 
$\checkmark$ If the TRL is 5 or more at FOA conclusion, then describe the preliminary targets for reliability and maintainability — and the strategy to obtain these targets - at the project conclusion, per Section 4.9 of this framework.

$\checkmark$ List the planned risk management deliverables during the FOA period of performance, i.e., as stated in Table 3 of the MHK Risk Management Framework (or equivalent), that apply to this project.

$\checkmark$ List the relevant standards to be used during the technology development under this FOA.

$\checkmark$ List the top 10 expected project risks. Then, analyze and provide risk responses for these 10 preliminary risks according to Section 5 of this framework; complete the MHK risk register template spreadsheet [17], or equivalent for these 10 preliminary risks. 


\section{Appendix B-Failure Mode Trend Analysis}

This appendix describes a method for tracking and trending failure modes during an MHK deployment. For consistency, the same failure modes and severity level definitions should be used when quantifying failure occurrence (see Table 11). Any modifications to the failure mode and severity level definitions should be completed before data is collected.

This method can track failure trends over a single project, or it can be applied to aggregated data from multiple projects. Trends should be tracked separately for each failure mode. The time period for data collection should be consistent within a single project and across multiple projects (e.g., data may be collected during one-year periods). The occurrence of each failure mode and severity should be tabulated during each period. Some failure modes may occur multiple times at various severity levels during a period (e.g. loss of functionality), while other failure modes will only have one occurrence during a given period (e.g. availability).

A hypothetical example of failure data during three periods is shown in Tables 12 through 14 . All failure modes during a given period can be displayed in a graph such as Figure 4. Trends across all periods for a single failure mode can be displayed in a graph such as Figure 5.

\section{Failure Modes and Severity Definitions}

Table 11. Failure Mode Severity Definitions for Trend Analysis

\begin{tabular}{|c|c|c|c|c|c|c|c|}
\hline \multirow[t]{2}{*}{ ID } & \multirow[t]{2}{*}{ Failure mode } & \multicolumn{6}{|c|}{ Severity Level Definitions } \\
\hline & & 0 & 1 & 2 & 3 & 4 & 5 \\
\hline 1 & $\begin{array}{l}\text { Loss of functionality } \\
\text { definitions [7] }\end{array}$ & None & $\begin{array}{l}\text { Minimal } \\
\text { effect, } \\
\text { easily } \\
\text { repairable } \\
\text { or } \\
\text { redundant } \\
\text { system }\end{array}$ & $\begin{array}{l}\text { Loss of } \\
\text { redundant } \\
\text { function, } \\
\text { reduced } \\
\text { capacity }\end{array}$ & $\begin{array}{l}\text { Loss of } \\
\text { parts of } \\
\text { main } \\
\text { function, } \\
\text { with } \\
\text { significant } \\
\text { repairs } \\
\text { required }\end{array}$ & $\begin{array}{l}\text { Subsystem } \\
\text { failure; } \\
\text { system } \\
\text { requires } \\
\text { retrieval }\end{array}$ & $\begin{array}{l}\text { Complete } \\
\text { failure }\end{array}$ \\
\hline 1.1 & $\begin{array}{l}\text { Loss of functionality- } \\
\text { PTO or rotor assembly }\end{array}$ & \multicolumn{6}{|c|}{ See: Loss of functionality definitions } \\
\hline 1.2 & $\begin{array}{l}\text { Loss of functionality- } \\
\text { electrical systems }\end{array}$ & \multicolumn{6}{|c|}{ See: Loss of functionality definitions } \\
\hline 1.3 & $\begin{array}{l}\text { Loss of functionality- } \\
\text { mechanical systems }\end{array}$ & \multicolumn{6}{|c|}{ See: Loss of functionality definitions } \\
\hline 1.4 & $\begin{array}{l}\text { Loss of functionality- } \\
\text { wear items (seals, } \\
\text { bearings, etc.) }\end{array}$ & \multicolumn{6}{|c|}{ See: Loss of functionality definitions } \\
\hline 1.5 & $\begin{array}{l}\text { Loss of functionality- } \\
\text { structure (break, fatigue, } \\
\text { etc.) }\end{array}$ & \multicolumn{6}{|c|}{ See: Loss of functionality definitions } \\
\hline 1.6 & $\begin{array}{l}\text { Loss of functionality- } \\
\text { mooring or foundation }\end{array}$ & \multicolumn{6}{|c|}{ See: Loss of functionality definitions } \\
\hline
\end{tabular}




\begin{tabular}{|c|c|c|c|c|c|c|c|}
\hline \multirow[t]{2}{*}{ ID } & \multirow[t]{2}{*}{ Failure mode } & \multicolumn{6}{|c|}{ Severity Level Definitions } \\
\hline & & 0 & 1 & 2 & 3 & 4 & 5 \\
\hline 1.7 & $\begin{array}{l}\text { Loss of functionality- } \\
\text { control system }\end{array}$ & \multicolumn{6}{|c|}{ See: Loss of functionality definitions } \\
\hline 1.8 & $\begin{array}{l}\text { Loss of functionality- } \\
\text { data/monitoring system }\end{array}$ & \multicolumn{6}{|c|}{ See: Loss of functionality definitions } \\
\hline 1.9 & $\begin{array}{l}\text { Loss of functionality- } \\
\text { other }\end{array}$ & \multicolumn{6}{|c|}{ See: Loss of functionality definitions } \\
\hline 2 & Loss of device ( $\%$ loss $)$ & None & Temporary & $\begin{array}{l}\text { Light } \\
\text { Damage } \\
(25 \%)\end{array}$ & $\begin{array}{l}\text { Damage } \\
(50 \%)\end{array}$ & $\begin{array}{l}\text { Severe } \\
\text { Damage } \\
(75 \%)\end{array}$ & $\begin{array}{l}\text { Total Loss } \\
(100 \%)\end{array}$ \\
\hline 3 & $\begin{array}{l}\text { Reduced power } \\
\text { production compared to } \\
\text { expectations/predictions }\end{array}$ & $>90 \%$ & $80-90 \%$ & $50-80 \%$ & $20-50 \%$ & $10-20 \%$ & $<10 \%$ \\
\hline 4 & Low availability & $>90 \%$ & $80-90 \%$ & $50-80 \%$ & $20-50 \%$ & $10-20 \%$ & $<10 \%$ \\
\hline 5 & $\begin{array}{l}\text { Incomplete data amount } \\
\text { collected during period }\end{array}$ & $>90 \%$ & $80-90 \%$ & $50-80 \%$ & $20-50 \%$ & $10-20 \%$ & $<10 \%$ \\
\hline 6 & $\begin{array}{l}\text { Delay in deployment or } \\
\text { commissioning }\end{array}$ & None & $\begin{array}{l}\text { Less than } \\
\text { one week } \\
\text { delay }\end{array}$ & $\begin{array}{l}1 \text { week to } \\
1 \text { month } \\
\text { delay }\end{array}$ & $\begin{array}{l}1 \text { month to } \\
6 \text { months } \\
\text { delay }\end{array}$ & $\begin{array}{l}6 \text { months } \\
\text { to } 1 \text { year } \\
\text { delay }\end{array}$ & never \\
\hline 7 & $\begin{array}{l}\text { Breach of safety } \\
\text { requirements }\end{array}$ & None & Nuisance & $\begin{array}{l}\text { Minor } \\
\text { injuries }\end{array}$ & $\begin{array}{l}\text { Significant } \\
\text { injuries } \\
\text { and/or } \\
\text { health } \\
\text { effects }\end{array}$ & $\begin{array}{l}\text { Life } \\
\text { threatening } \\
\text { injuries } \\
\text { and/or } \\
\text { health } \\
\text { effects }\end{array}$ & Fatality \\
\hline 8 & Other & TBD & TBD & TBD & TBD & TBD & TBD \\
\hline
\end{tabular}




\section{Failure Mode Trend Analysis Hypothetical Example \#1}

The following subsection contains a hypothetical application of the failure trend analysis described in Table 11. This example shows data from three consecutive periods (Tables 12 through 14). The numbers within each table are the quantity of occurrence of each failure mode at the stated severity level during the period.

Table 12. Hypothetical Example \#1-Failure Trend Analysis Period 1

\begin{tabular}{|c|c|c|c|c|c|c|c|}
\hline \multirow[t]{2}{*}{ ID } & \multirow[t]{2}{*}{ Failure mode } & \multicolumn{6}{|c|}{ Failure Occurrence During Period for each Severity Level } \\
\hline & & 0 & 1 & 2 & 3 & 4 & 5 \\
\hline 1.1 & $\begin{array}{l}\text { Loss of functionality- } \\
\text { PTO or rotor assembly }\end{array}$ & 1 & & & & & \\
\hline 1.2 & $\begin{array}{l}\text { Loss of functionality- } \\
\text { electrical systems }\end{array}$ & & 2 & & 3 & & \\
\hline 1.3 & $\begin{array}{l}\text { Loss of functionality- } \\
\text { mechanical systems }\end{array}$ & & 1 & & & & \\
\hline 1.4 & $\begin{array}{l}\text { Loss of functionality- } \\
\text { wear items (seals, } \\
\text { bearings, etc.) }\end{array}$ & 1 & & & & & \\
\hline 1.5 & $\begin{array}{l}\text { Loss of functionality- } \\
\text { structure (break, fatigue, } \\
\text { etc.) }\end{array}$ & 1 & & 2 & & & \\
\hline 1.6 & $\begin{array}{l}\text { Loss of functionality- } \\
\text { mooring or foundation }\end{array}$ & 1 & & & & & \\
\hline 1.7 & $\begin{array}{l}\text { Loss of functionality- } \\
\text { control system }\end{array}$ & & & 1 & & & \\
\hline 1.8 & $\begin{array}{l}\text { Loss of functionality- } \\
\text { data/monitoring system }\end{array}$ & & 1 & & & & \\
\hline 2 & Loss of device (\% loss) & & 1 & & & & \\
\hline 3 & $\begin{array}{l}\text { Reduced power } \\
\text { production compared to } \\
\text { expectations/predictions }\end{array}$ & 1 & & & & & \\
\hline 4 & Low availability & 1 & & & & & \\
\hline 5 & $\begin{array}{l}\text { Incomplete data amount } \\
\text { collected during period }\end{array}$ & & 1 & & & & \\
\hline 6 & $\begin{array}{l}\text { Delay in deployment or } \\
\text { commissioning }\end{array}$ & 1 & & & & & \\
\hline 7 & $\begin{array}{l}\text { Breach of safety } \\
\text { requirements }\end{array}$ & & & 3 & & & \\
\hline
\end{tabular}


Table 13 contains hypothetical failure-mode-occurrence data during the second analyzed period. The increase in safety incidents from the first period may indicate a growing need to manage safety risks.

Table 13. Hypothetical Example \#1-Failure Trend Analysis Period 2

\begin{tabular}{|c|c|c|c|c|c|c|c|}
\hline \multirow[t]{2}{*}{ ID } & \multirow[t]{2}{*}{ Failure mode } & \multicolumn{6}{|c|}{ Failure Occurrence During Period for each Severity Level } \\
\hline & & 0 & 1 & 2 & 3 & 4 & 5 \\
\hline 1.1 & $\begin{array}{l}\text { Loss of functionality- } \\
\text { PTO or rotor assembly }\end{array}$ & 1 & & & & & \\
\hline 1.2 & $\begin{array}{l}\text { Loss of functionality- } \\
\text { electrical systems }\end{array}$ & & 2 & & & 1 & \\
\hline 1.3 & $\begin{array}{l}\text { Loss of functionality- } \\
\text { mechanical systems }\end{array}$ & 1 & & & & & \\
\hline 1.4 & $\begin{array}{l}\text { Loss of functionality- } \\
\text { wear items (seals, } \\
\text { bearings, etc.) }\end{array}$ & 1 & & & & & \\
\hline 1.5 & $\begin{array}{l}\text { Loss of functionality- } \\
\text { structure (break, fatigue, } \\
\text { etc.) }\end{array}$ & 1 & & & & & \\
\hline 1.6 & $\begin{array}{l}\text { Loss of functionality- } \\
\text { mooring or foundation }\end{array}$ & 1 & & & & & \\
\hline 1.7 & $\begin{array}{l}\text { Loss of functionality- } \\
\text { control system }\end{array}$ & & 1 & & & & \\
\hline 1.8 & $\begin{array}{l}\text { Loss of functionality- } \\
\text { data/monitoring system }\end{array}$ & 1 & & & & & \\
\hline 2 & Loss of device (\% loss) & 1 & & & & & \\
\hline 3 & $\begin{array}{l}\text { Reduced power } \\
\text { production compared to } \\
\text { expectations/predictions }\end{array}$ & 1 & & & & & \\
\hline 4 & Low availability & 1 & & & & & \\
\hline 5 & $\begin{array}{l}\text { Incomplete data amount } \\
\text { collected during period }\end{array}$ & & & 1 & & & \\
\hline 6 & $\begin{array}{l}\text { Delay in deployment or } \\
\text { commissioning }\end{array}$ & 1 & & & & & \\
\hline 7 & $\begin{array}{l}\text { Breach of safety } \\
\text { requirements }\end{array}$ & & & 5 & & & \\
\hline
\end{tabular}


Table 14 contains hypothetical failure-mode-occurrence data during the third analyzed period. The increase in severity for the safety incidents indicates a higher priority is necessary for managing safety risks, even though no other failure modes occurred during this period.

Table 14. Hypothetical Example \#1-Failure Trend Analysis Period 3

\begin{tabular}{|c|c|c|c|c|c|c|c|}
\hline \multirow[t]{2}{*}{ ID } & \multirow[t]{2}{*}{ Failure mode } & \multicolumn{6}{|c|}{ Failure Occurrence During Period for each Severity Level } \\
\hline & & 0 & 1 & 2 & 3 & 4 & 5 \\
\hline 1.1 & $\begin{array}{l}\text { Loss of functionality- } \\
\text { PTO or rotor assembly }\end{array}$ & 1 & & & & & \\
\hline 1.2 & $\begin{array}{l}\text { Loss of functionality- } \\
\text { electrical systems }\end{array}$ & 1 & & & & & \\
\hline 1.3 & $\begin{array}{l}\text { Loss of functionality- } \\
\text { mechanical systems }\end{array}$ & 1 & & & & & \\
\hline 1.4 & $\begin{array}{l}\text { Loss of functionality- } \\
\text { wear items (seals, } \\
\text { bearings, etc.) }\end{array}$ & 1 & & & & & \\
\hline 1.5 & $\begin{array}{l}\text { Loss of functionality- } \\
\text { structure (break, fatigue, } \\
\text { etc.) }\end{array}$ & 1 & & & & & \\
\hline 1.6 & $\begin{array}{l}\text { Loss of functionality- } \\
\text { mooring or foundation }\end{array}$ & 1 & & & & & \\
\hline 1.7 & $\begin{array}{l}\text { Loss of functionality- } \\
\text { control system }\end{array}$ & 1 & & & & & \\
\hline 1.8 & $\begin{array}{l}\text { Loss of functionality- } \\
\text { data/monitoring system }\end{array}$ & 1 & & & & & \\
\hline 2 & Loss of device (\% loss) & 1 & & & & & \\
\hline 3 & $\begin{array}{l}\text { Reduced power } \\
\text { production compared to } \\
\text { expectations/predictions }\end{array}$ & 1 & & & & & \\
\hline 4 & Low availability & 1 & & & & & \\
\hline 5 & $\begin{array}{l}\text { Incomplete data amount } \\
\text { collected during period }\end{array}$ & 1 & & & & & \\
\hline 6 & $\begin{array}{l}\text { Delay in deployment or } \\
\text { commissioning }\end{array}$ & 1 & & & & & \\
\hline 7 & $\begin{array}{l}\text { Breach of safety } \\
\text { requirements }\end{array}$ & & & & 1 & 2 & \\
\hline
\end{tabular}


Figure 4 is a graph of all the failure mode data from Period 1. This figure provides a method for viewing data from Table 12.

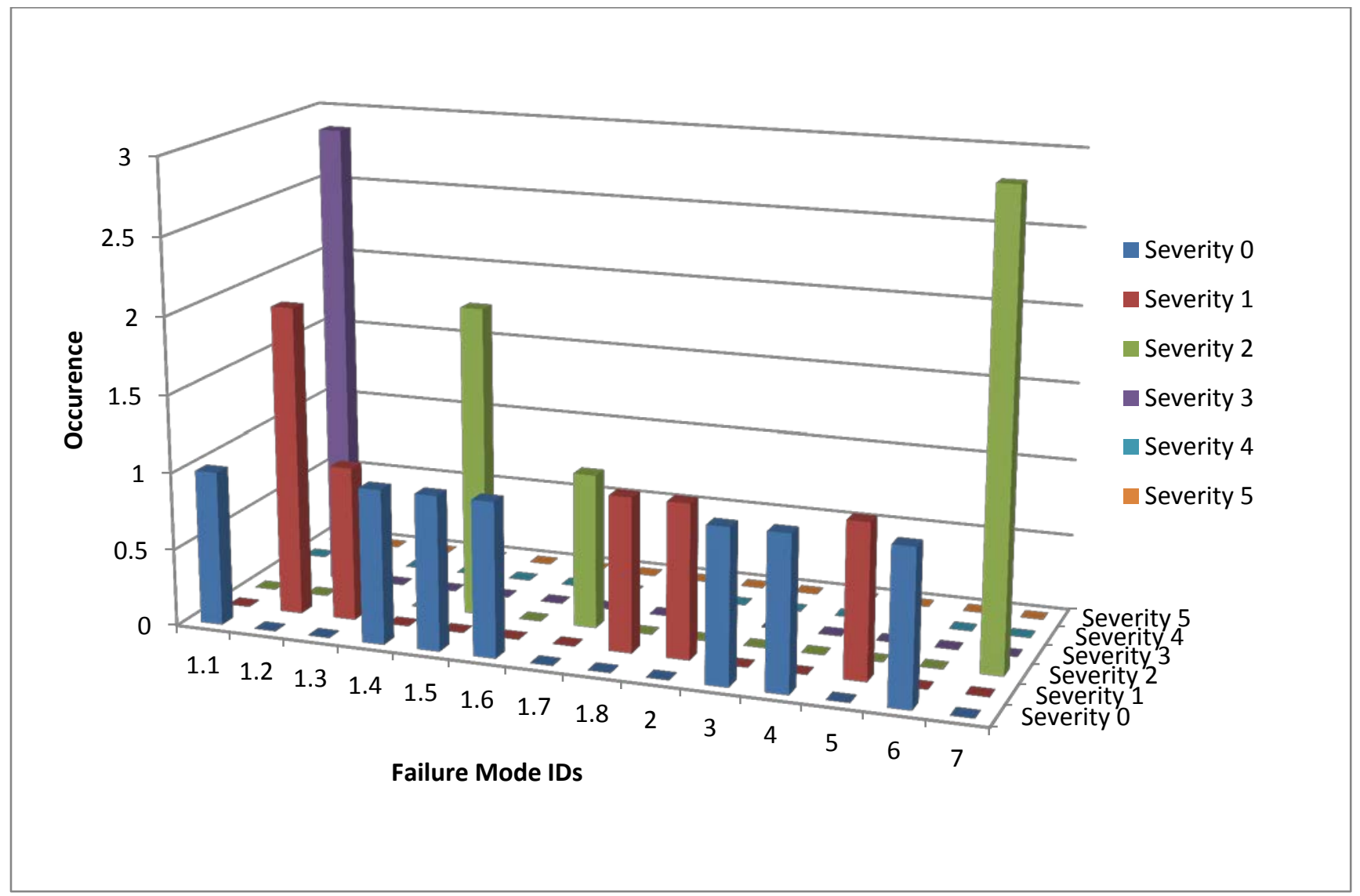

Figure 4. Hypothetical analysis \#1—failure mode occurrences during Period 1 
Figure 5 shows the failure trends across three time periods for Failure Mode 7 (safety incidents). As shown, there is a trend of increased severity from period 2 to period 3 . This type of figure shows how failure mode trends can be tracked through time for a range of severities.

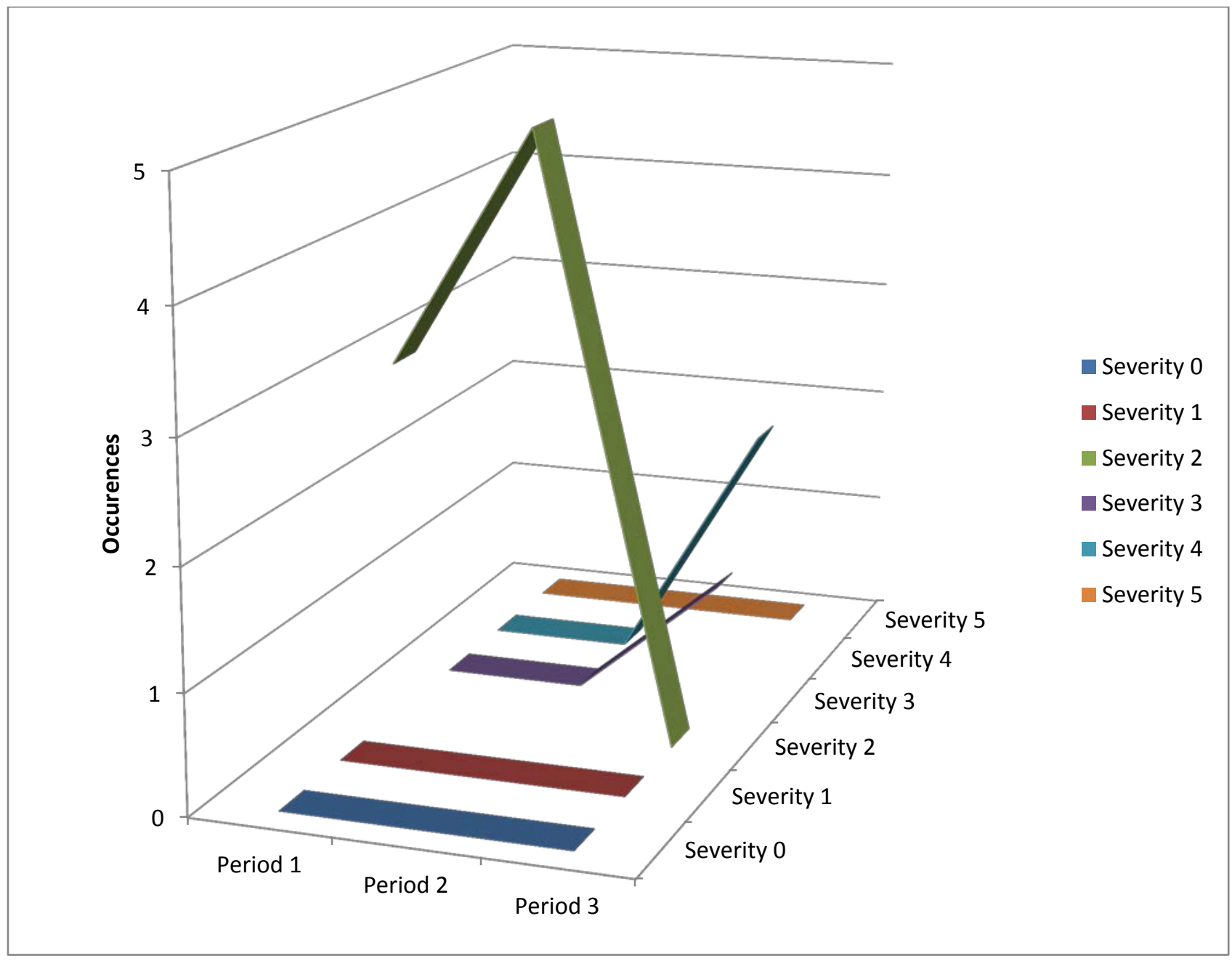

Figure 5. Hypothetical analysis \#1—failure trends over three periods for Failure Mode 7 


\section{Appendix C-Risk Management Outlined Bibliography (Standards, Guides \& Reports)}

The following is an outlined bibliography for further reading on topics related to MHK risk management. The underlined text contains external links to the source document; the nonunderlined references must be purchased to view. There is no particular order to the information presented here.

\section{Terminology}

IEC 62600-1, MHK Terminology [23]

ISO 73, Risk Vocabulary [24]

\section{Certification \& Qualification Guidelines}

DNV-RP-A203, Technology Qualification [12]

DNV-OSS-312, MHK Certification Standard [25]

\section{General \& Marine Risk Management}

$P M B O K, 5^{\text {th }}$ edition [4]

Practice Standard for Project Risk Management [18]

ISO 31000 Risk Management Guideline [26]

IEC ISO 31010 Risk Management Techniques [20]

DNV-RP-H101 Risk Management in Marine Operations [27]

ABS Offshore Oil Risk Assessment [28]

API 17N Subsea Risk Management [29]

ATOM Risk website contains several risk management templates and examples [19]

Marine risk assessment, Offshore Technology Report, DNV_-2001/063 [30]

Failure Management

IEC 60812, FMEA Analysis Techniques [10]

DNV-RP-D102, FMEA of Redundant Systems [31]

IMCA M166, Guidance on FMEA [32]

DOD MIL-STD-1629RevA FMEA Procedure [33]

IEC 61025, Fault Tree Analysis [34] 
IEC 61078, Reliability Block Diagram [35]

IEC 62502, Event Tree Analysis Techniques [36]

\section{Design \& Testing Guidelines}

DNV WEC design guideline [7]

EMEC design basis guideline [6]

EMEC reliability, maintainability, and survivability guideline [9]

- Annex F defines risk in terms of equipment maturity and organizational capability

OES Guideline by Holmes, for testing wave energy systems [15]

-provides a test validation outline based on technology TRL.

EquiMar Protocols for assessing marine energy converters [13]

DNV-OS-C501 Composite Components [37]

ITTC Guideline for model test experiments [14]

IEC 62600-10 Mooring systems [38]

ABS Offshore Fatigue Assessment Guide [39]

GL Offshore Structural Design Guide [40]

Safety Management

ISO 12100 Safety of Machinery [41]

\section{TRL \& TPL Definitions}

DOE TRL assessment guide, see Table 1 [1]

NASA TRL definitions [42]

Appendix 2 Technology Readiness Levels for Supply Chain Study for WestWave, provides TRL functional definitions for wave power devices \& a verification checklist [8].

Weber TPL papers from ICOE and EWTEC conferences [2] [3]

\section{Miscellaneous}

DNV-OS-D201 Offshore Electrical Installations, DNV, October 2013 [43]

Review of the risk assessment of buoyancy loss (RABL) project, by R.G. Standing from BMT Fluid Mechanics Limited, 2003; this document exemplifies the importance of risk management [44] 
Tidal Turbine That Survive, presentation from University of Southampton [45]

Reliability-Based Fatigue Design of Marine Current Turbine Rotor Blades, Master thesis by Shaun Hurley [46]

Tidal Current Turbine Fatigue Loading Sensitivity to Waves and Turbulence - a Parametric Study, GL Paper [47]

Evaluation of the Durability of Composite Tidal Turbine Blades, by Peter Davies, et al. Provides framework for rotor blade qualification [48]

DNV-RP-C205, Environmental Conditions and Environmental Loads, DNV, October 2010 [49] 


\section{Appendix D-MHK Lessons Learned (Publically Available Information):}

The following contains publicly available articles or reports on MHK lessons learned, collected for the express purpose of managing negative risk in future projects. All articles were drawn from websites accessible in November 2014, and, as such, only include information in the public domain. No endorsement or repudiation of the designs or companies mentioned in the articles is implied by their inclusion in this list; nor does this report make any claims regarding the veracity of the information present therein.

The following are some common themes from this information:

- Rotor blade failures

- Operational loads and tidal/wave resources have not always been well understood

- Transporting/installing the system may have unanticipated loads/complexities

- Buoyant components have sinking risk

- Small failures may cascade to system failures

\section{Breach of Water Integrity of Compartments or Equipment:}

http://www.publications.parliament.uk/pa/cm200001/cmselect/cmsctech/291/1031409.htm

\section{Electrical Failures and Shore Connector Failures / Pressure} Containment Failure from Hydraulic or Pneumatic Systems:

http://www.aquamarinepower.com/news/oyster-800-back-in-operation/

\section{Structural Failure:}

http://www.oceanrenewable.com/2011/09/12/atlantis-resources-corporation-connects-1mw-tidalturbine-to-the-national-grid/

http://www.bbc.co.uk/news/uk-scotland-highlands-islands-11492829

\section{Breach of Water Integrity of Compartments or Equipment:}

http://www.renewableenergyworld.com/rea/news/article/2007/11/while-finaveras-buoy-sinkshopes-of-harnessing-ocean-energy-survive-50510

\section{Electrical Failures and Shore Connector Failures / Structural Failure:}

http://www.marineturbines.com/3/news/article/11/delay_in_commissioning_one_of_seagen_s_ro $\underline{\text { tors }}$

$\underline{\text { http://en.wikipedia.org/wiki/Marine Current Turbines }}$

\section{Mooring Failure / Breach of Water Integrity of Compartments or Equipment: \\ http://cleantechnica.com/2010/05/22/massive-offshore-waves-sink-australias-oceanlinx- wavepower-pilot/}




\section{Breach of Water Integrity of Compartments or Equipment I Bankruptcy:}

http://www.adelaidenow.com.au/news/south-australia/oceanlinx-forced-to-tow-wave-energyconverter-out-of-troubled-waters-off-the-fleurieu-peninsula/story-fni6uolm-1226844686996 http://www.abc.net.au/news/2014-04-01/oceanlinx-wave-energy-generatorjpg/5359456 http://www.abc.net.au/news/2014-04-02/support-aired-for-oceanlinx-project-ascreditors/5361898

http://www.businessspectator.com.au/news/2014/4/2/renewable-energy/oceanlinx-goesbankrupt-owing-10m

http://www.offshorewind.biz/2014/04/15/video-oceanlinx-wave-energy-generator-stuck-offcarrickalinga/

\section{Structural Failure:}

http://www.greentechmedia.com/articles/read/a-big-setback-for-tidal-power http://www.cbc.ca/news/canada/nova-scotia/failed-tidal-turbine-explained-at-symposium$\underline{1.1075510}$ http://www.renewableenergyfocus.com/view/14766/openhydro-tidal-turbine-recovered-bladesmissing/

\section{Structural Failure / Breach of Water Integrity of Compartments or Equipment / Regulatory:}

http://www.adelaidenow.com.au/news/south-australia/oceanlinx-forced-to-tow-wave-energyconverter-out-of-troubled-waters-off-the-fleurieu-peninsula/story-fni6uolm-1226844686996 http://www.oregonlive.com/environment/index.ssf/2013/08/oregon wave energy stalls off.html

\section{Electrical Failures and Shore Connector Failures:}

https://bangordailynews.com/2013/04/10/news/down-east/year-one-of-eastport-tidal-turbineresearch-presents-challenges/

\section{Breach of Water Integrity of Compartments or Equipment / Bankruptcy:}

http://www.treehugger.com/renewable-energy/portugals-pelamis-wave-power-project-dead-inthe-water.html

http://www.rechargenews.com/news/wave tidal hydro/article1282035.ece http://www.pelamiswave.com/news/news/173/Pelamis-Wave-Power-Limited-Pelamis-to-be-putinto-administration

\section{Structural Failure:}

http://dnr.alaska.gov/mlw/wslca/appendix_g/verdant_power_marine_renewables.pdf 


\section{Breach of Water Integrity of Compartments or Equipment}

http://www.modec.com/up_pdf/20141218_pr_skwid_en.pdf

\section{[Summary Report by Manufacturer]:}

http://www.jupiterhydro.com/SiteAssets/industry/IcfMarbek\%20Tidal\%20Energy\%20Report 20

\%2009\%2012 Final.pdf

http://www.osti.gov/scitech/servlets/purl/1115743

http://www.osti.gov/scitech/servlets/purl/1124124

http://www.osti.gov/scitech/servlets/purl/1111482

http://www.osti.gov/scitech/biblio/1097595 